\title{
Perspectives for solid biopolymer electrolytes in dye sensitized solar cell and battery application
}

\author{
Rahul Singh ${ }^{\mathrm{a}, \mathrm{b}, *}$, Anji Reddy Polu ${ }^{\mathrm{c}, \mathrm{d}}, \mathrm{B}$. Bhattacharya ${ }^{\mathrm{a}}$, Hee-Woo Rhee ${ }^{\mathrm{c}}$, Canan Varlikli ${ }^{\mathrm{e}}$, \\ Pramod K. Singh ${ }^{\text {a,f,* }}$ \\ a Material Research Laboratory, School of Basic Sciences and Research, Sharda University, G. Noida 201 310, India \\ ${ }^{\mathrm{b}}$ School of Electrical and Computer Engineering, Purdue University, West Lafayette, IN 47907, USA \\ ${ }^{\mathrm{c}}$ Polymer Materials Lab, Department of Chemical and Biomolecular Engineering, Sogang University, 35 Baekbeom-Ro, Mapo-Gu, Seoul 121-742, Republic of \\ Korea \\ ${ }^{\mathrm{d}}$ Department of Physics, Vardhaman College of Engineering (UGC-Autonomous), Kacharam, Shamshabad-501218, Hyderabad, Telangana, India \\ e Izmir Institute of Technology, Department of Photonics, 35430 Urla, Izmir, Turkey \\ ${ }^{\mathrm{f}}$ Solar Energy Institute, Ege University, Bornova 35100, Turkey
}

\section{A R T I C L E I N F O}

\section{Article history:}

Received 25 September 2015

Received in revised form

6 May 2016

Accepted 16 June 2016

Available online 30 July 2016

\section{Keywords:}

Biopolymer

Conductivity

Dye sensitized solar cell

Ionic liquid

Battery

\begin{abstract}
A B S T R A C T
Photovoltaic technologies represent one of the leading research areas of solar energy which is one of the most powerful renewable alternatives of fossil fuels. In a common photovoltaic application the batteries play a key role in storage of energy generated by solar panels. Although it will take time for dye sensitized solar cells (DSSCs) and batteries based on biopolymer electrolytes to take their places in the market, laboratory studies prove that they have a lot to offer. Most efficient DSSCs and batteries available in market are based on liquid electrolytes. The advantages of liquid electrolytes are having high conductivity and good electrode-electrolyte interface whereas, disadvantages like corrosion and evaporation limit their future sustainability. Biopolymer electrolytes are proposed as novel alternatives which may overcome the problems stated above. In this review, we focus on fabrication, working principle as well as up to date status of DSSCs and batteries using biopolymer electrolytes. The effects of structural and electrical properties of biopolymer based electrolytes on the solar energy conversion efficiencies of DSSCs and their compatibility with lithium or other salts in battery applications are summarized. Biopolymer electrolyte based DSSCs are categorized on the basis of types of additives and recent outcomes of author's laboratory studies on biopolymer electrolyte based DSSCs and batteries are also presented.
\end{abstract}

(c) 2016 Published by Elsevier Ltd.

\section{Contents}

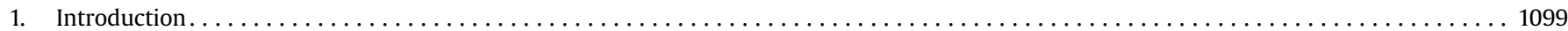

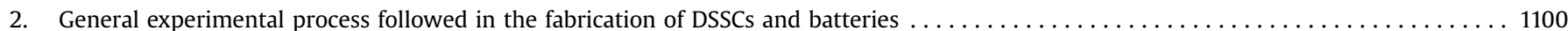

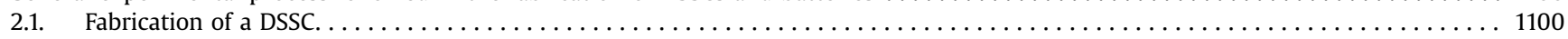

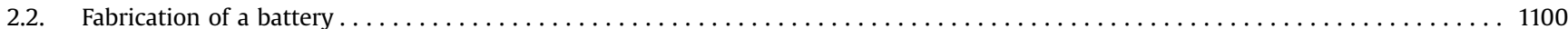

\footnotetext{
Abbreviations: DMSO, dimethyl sulfoxide; PC, Propylene carbonates; PG, Propylene glycol; 3EG, Triethylene glycol; 4EG, Tetraethylene glycol; MPII, 1-methyl-3-proplylimidazolium iodide; (AEII), 1-allyl-3-ethylimidadolium iodide; (APII), 1-allyl-3-propylimidazolium iodide; (DAII), 1-3-diallylimidazolium iodide; SDS, Sodium dodecyl sulphate; PVP, Polyvinylpyrrolidone; PEG200, Polyethylene glycol; TW-80, Polysorbate 80-TW-80; NMP, 1-methyl-2-pyrrolidinone; GBL, $\gamma$-butyrolactone; PEO-HPC, Poly (ethylene oxide)-2-hydroxypropylcellulose; BmImTf, 1-butyl-3-methylimidazolium trifluoromethanesulfonate; LITFSI, Lithium bis(trifluoromethanesulfonyl)imide; DES, Deep eutectic solvent; [Amim] Cl, 1-allyl-3-methylimidazolium chloride; BmImPF6, 1-butyl-3-methylimidazolium hexafluorophosphate; DMAc, N, N-dimethylacetamide; LiCl, Lithium chloride; [BMIM]Cl, 1-butyl-3-methylimidazolium chloride; EC, Ethylene carbonates; PEG, Poly (ethylene glycol); LiTFSI, Lithium trifluoromethanesulfonimide; SPEEK-CS, sulfonated poly(ether ether ketone)-chitosan; DAP, Diethanolamine modified pectin; BC, Bacterial cellulose; TEA, triethanolamine; GA, glutaraldehyde; DTAB, dodecyltrimethyl ammonium bromide; EMImSCN, 1-ethyl 3-methylimidazolium thiocyanate; N3, Cis-Bis(isothiocyanato)bis(4,40-dicarboxyl-2,20-bipyridine)-ruthenium(II), Ru(dcbpy)2 (NCS)2; N719, Cis-bis(isothiocyanato)bis(2,2'-bipyridy1-4,4'-dicarboxylato)-ruthenium(II)bis-tetrabutylammonium; (AN), acetonitrile; (MOZ), 3-methyl-2-oxazolidinone; (Pr)4NI, tetrapropylammonium iodide; TBP, 4-tertiary butylpyridine; MPIm-I, 1-methyl-3-propylimidazolium iodide; DMHIm, 1, 2-dimethyl-3-nhexylimidazoliumiodide

* Corresponding authors at: Material Research Laboratory, School of Basic Sciences and Research, Sharda University, G. Noida 201 310, India.

E-mail addresses: www.newmail@gmail.com (R. Singh), pramodkumar.singh@sharda.ac.in (P.K. Singh).
} 


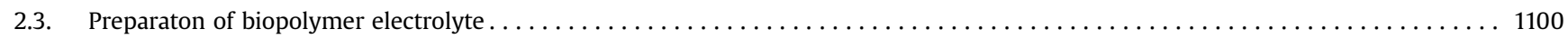

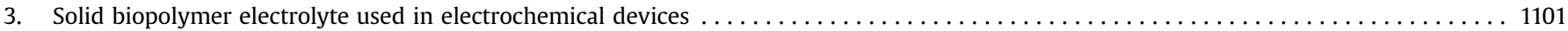

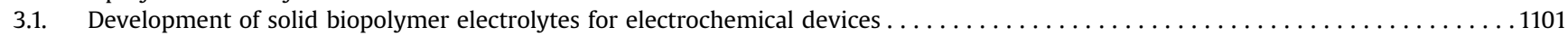

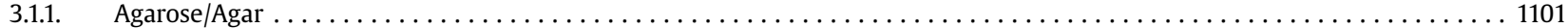

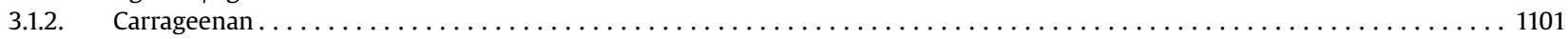

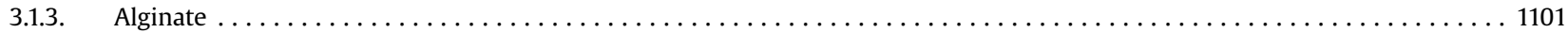

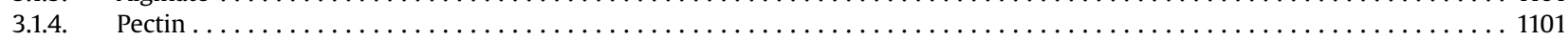

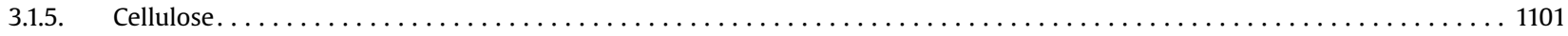

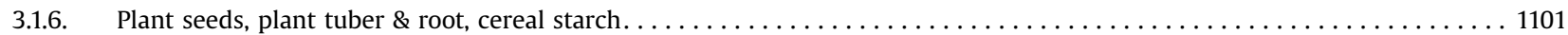

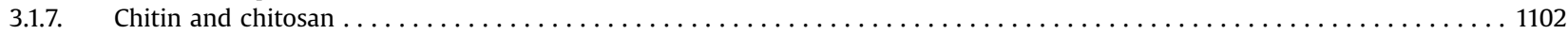

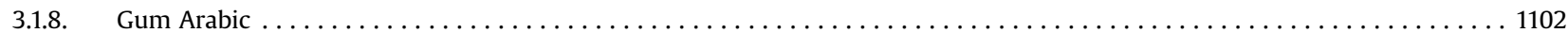

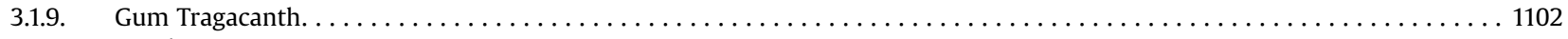

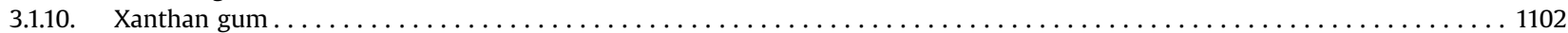

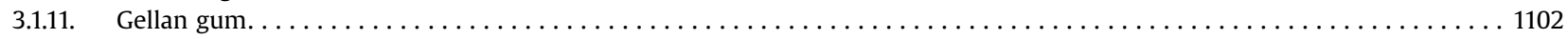

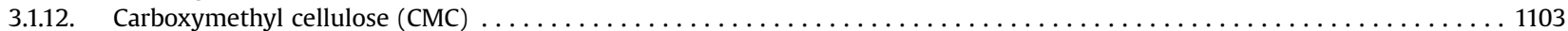

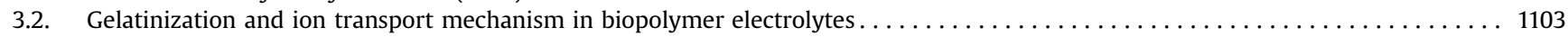

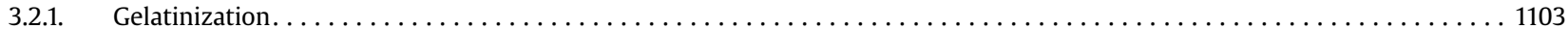

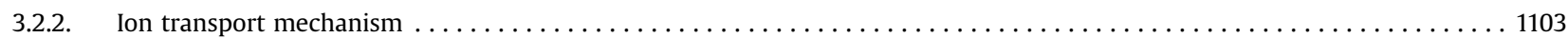

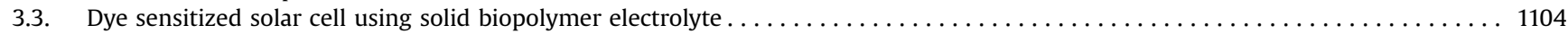

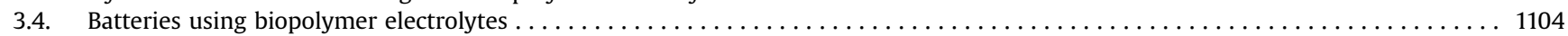

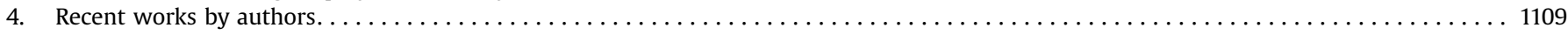

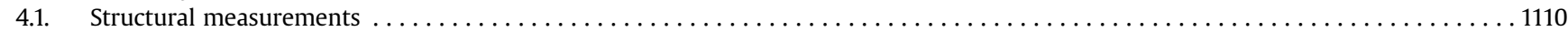

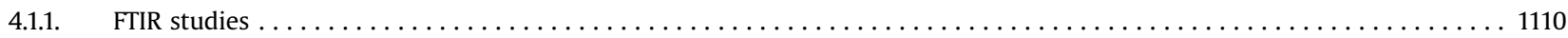

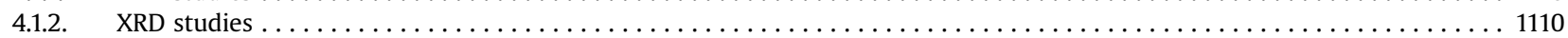

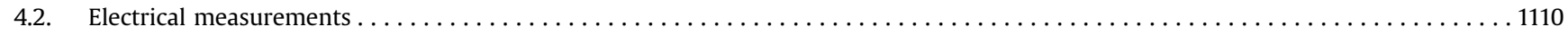

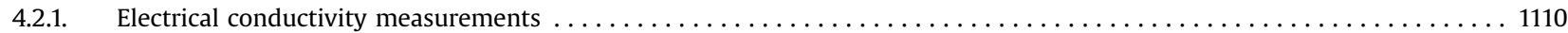

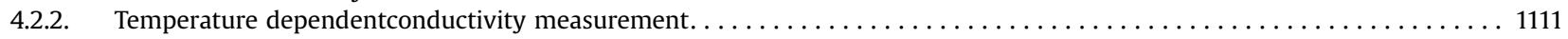

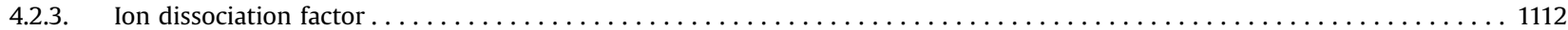

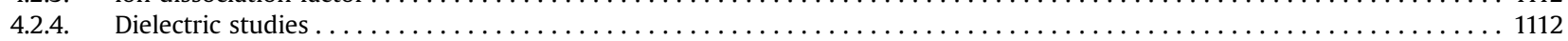

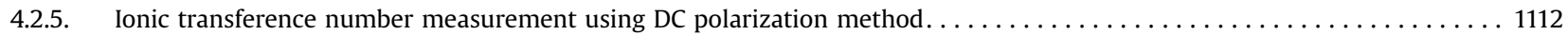

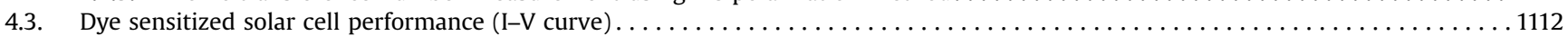

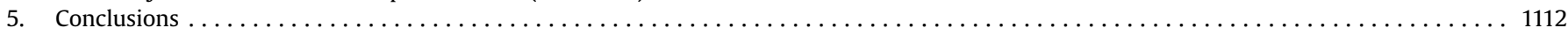

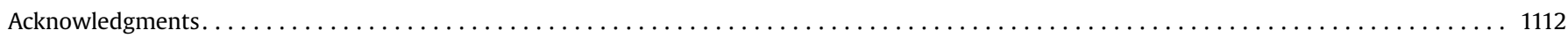

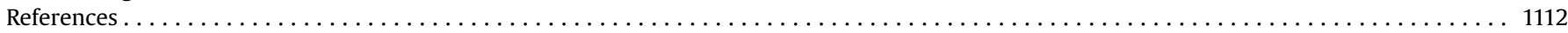

\section{Introduction}

Polymer electrolytes are one of the most important materials used in fabricating many electrochemical devices [1-5]. Polymers are classified into two main categories (1) synthetic and (2) natural. Most of the electrochemical devices available in market are based on liquid electrolyte. However solid polymer electrolytes (SPEs) which come into the category of synthetic polymers, offer more advantages over liquid electrolytes, such as higher energy density, flexible geometry, higher operating temperatures and safety, no-leakage of electrolyte and ease of application. The most commonly studied polymer electrolytes are the complexes of metal salts with high molecular weight polymer polyethylene oxide (PEO) [1-3]. However, one of the major drawbacks of PEObased solid polymer electrolytes is their low ionic conductivity $\left(10^{-7} \mathrm{~S} / \mathrm{cm}\right)$ at ambient temperature, which limits their practical applications [4,5]. To date, a large number of other synthetic polymers, such as polymethyl methacrylate (PMMA), poly acrylonitrile (PAN), poly(vinylidene fluoride-co-hexafluoropropylene) (PVdF-HFP), polyvinyl alcohol (PVA), and polyvinylpyrrolidone (PVP) etc, have been studied in electrolyte applications [6-9].

Especially in developing countries, environmental pollution caused by synthetic polymers is becoming a serious threat. Petroleum-derived plastics are not biodegradable; they do not undergo microbial degradation and hence accumulate in the environment. Together with the environmental concerns, tremendous increase in the prices of fossil fuel derived products force the scientist to focus on biodegradable polymers. Biopolymers fall into the natural polymers category, and represent one of the hot topics of polymer research. Since their introduction in 1980s, a vast number of biodegradable polymers have been synthesized [10-14] with the major goal of development of stable biopolymeric systems with excellent electrical and mechanical properties. Biopolymer electrolytes (BPEs) are solid ion conductors formed by dissolving salts in polymers having high molecular weight. They can be prepared in semisolid or solid form through cheap and reliable processes [15-27]. BPE materials possess high ionic conductivity $\left(10^{-2}\right.$ to $\left.10^{-4} \mathrm{~S} / \mathrm{cm}\right)$, high energy density,wide electrochemical stability window, provides solvent-free and leak proof condition, easy processability and light weight which are essential for any kind of electrochemical device, e.g. fuel cells [28], supercapacitors, batteries [29-32], dye sensitized solar cells (DSSCs) [33-290], etc. Due to the large variety of energy related BPE applications, the scope of this review is limited to the application of BPEs in DSSCs and batteries.

Since the introduction of DSSC technology by O'Regan and Grätzel in 1991, it represents one of the most studied photovoltaic technologies [46]. The conversion efficiencies vary between $6 \%$ and $13 \%$ depending on the size of active area, preparation conditions and the type of electrolyte [33]. Although the highest conversion efficiency has been achieved by using liquid electrolytes due to the stability problems generate mainly from the leakage of electrolyte, quasi gel electrolytes are introduced. However this kind of electrolytes could not solve the stability problem and also caused efficiency reductions generating from the low ionic mobility and trapping of the gel in the metal oxide pores [53-56]. The next proposed alternative is solid polymer electrolytes in which polyether's and biopolymer-salt complexes are playing the dominant role [76-88,105-109]. In addition to their high conductivity and good thermal stability, biodegradable thin/ thick film formation abilities make them suitable electrolyte candidates for DSSCs. 
It is well accepted that rechargeable batteries are the most dominant energy storage devices especially in automotive industry and portable electronic devices [1-3]. It is also identified that Li-ion batteries (LIBs) are the preferred system for electric vehicles, grid energies and flexible electronic devices due to their high energy and power density [4]. Particularly, flexible and wearable electronics are expected to increase an exceptional importance in the future as energy storage devices. The important parts in rechargeable batteries are anode, cathode and electrolytes. The electrolytes commonly used are traditional liquid based electrolytes containing organic solvents, which are volatile and flammable. This requires alternative electrolyte material which prevents the leakage of the liquid electrolyte as well as internal short circuit in LIBs due to lithium dendrite growth on the anodes. As a result, safety issues are the major concerns in the applications of batteries. In such a situation, the development of solid-state electrolytes is a major challenge to be faced by scientific research [1-5].

Nowadays, researchers focus on light, safe, environmentally friendly and sustainable devices for conversion and storage of energy, preferentially at low cost. Although there is almost no concerns on the added value of biopolymers in weight, safety and environmental issues, one may question the sustainability of biopolymers and may claim that utilization of them in energy sector may raise the price of food products and even lead to food crises. However, if one also considers that energy heads the top ten problems of today"s world and each and every attempt on minimizing it has the potential to minimize the influence of the others, i.e. water, food, environment, poverty, terrorism, disease, education, democracy, population [12], we think that not utilization of biopolymers in energy applications but, ignoring the energy problems will absolutely lead to food crises. Additionally, being one of the most widely known biopolymers cellulose, is the most abounded polymer in the world, recycling process of it is very well known and represents one of the most studied BPE component.

In this review, after the introduction of general experimental process followed in the fabrication of DSSCs and batteries and ion transport mechanism in biopolymer electrolytes, we summarized the literature on utilization of BPEs in electrochemical devices of DSSCs and batteries and presented our recent laboratory studies.

\section{General experimental process followed in the fabrication of DSSCs and batteries}

\subsection{Fabrication of a DSSC}

A DSSC comprises a sandwiched structure of two electrodes (anode, cathode) and electrolyte. The anode is prepared by the use of mesoporous metal oxides, e.g. $\mathrm{TiO}_{2}, \mathrm{ZnO}$ and the cathode is obtained by platinum coating on transparent conductive oxide. The $\mathrm{TiO}_{2}$ electrode is immersed in dye solution overnight and the space between the sandwiched electrodes is filled with an electrolyte. Under illumination, the cell produces current through an external load connected to the electrodes. The absorption of light in the DSSC occurs due to the dye molecules and charge separation by electron injection from the dye to the $\mathrm{TiO}_{2}$ at the semiconductor electrolyte interface (Fig. 1). The color of the device can be easily varied by the choice of dye [67-75]. The chemical and physical composition and structure of electrolyte mainly effects on the stability and solar energy conversion efficiency of the DSSC [49-55].

\subsection{Fabrication of a battery}

Batteries are composed of a cathode and ananode as the electrodes, a metal salt solution (or solid polymer electrolyte) as the

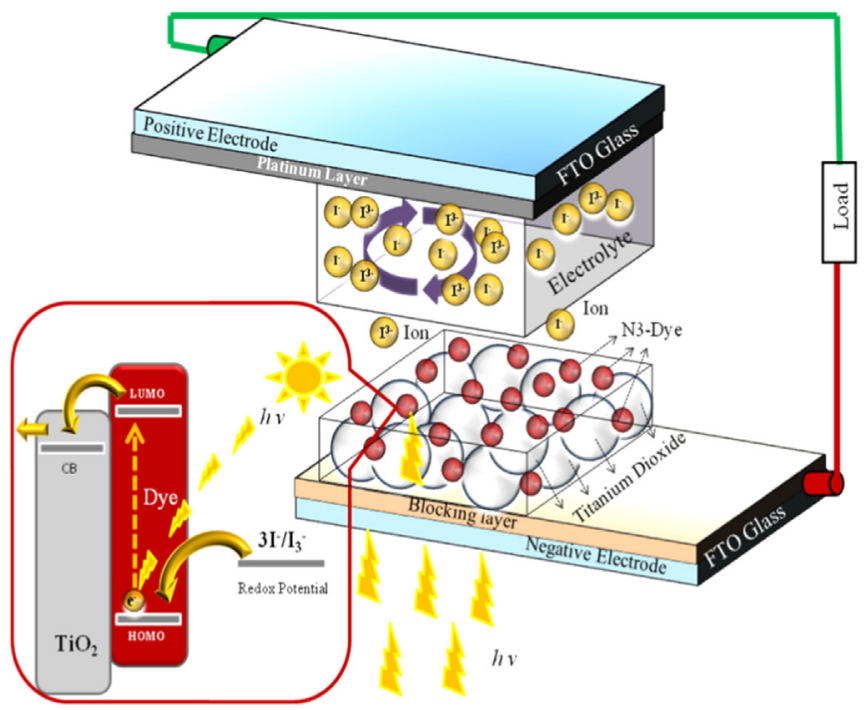

Fig. 1. Schematic diagram presenting working principle of dye sensitized solar cells (DSSC).

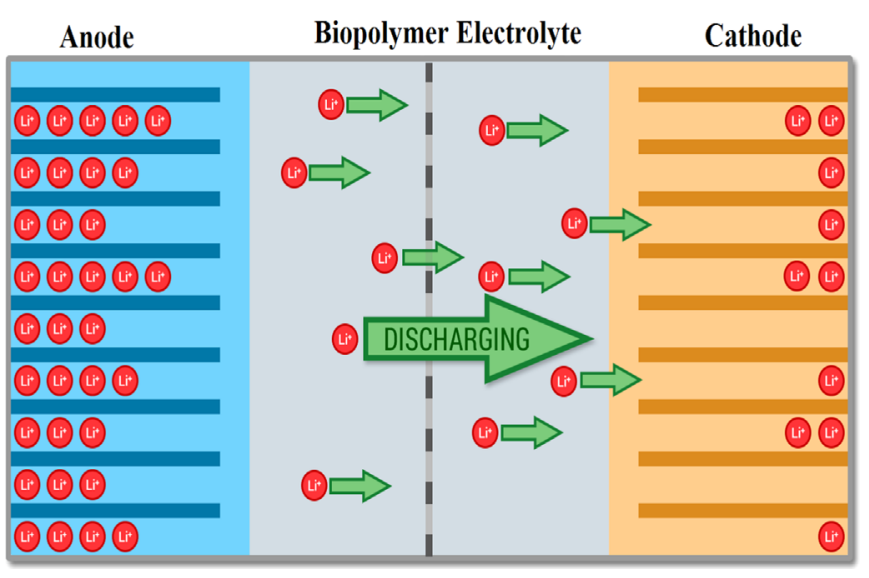

Fig. 2. Schematic diagram of Li-ion battery discharge.

electrolyte, a separator and functional additives which converts chemical into electrical energy. Copper and Aluminum foils are used as substrates for coating anode and cathode materials in rechargeable battery. The chemical reactions in the battery cause a buildup of electrons at the anode. This results in an electrical difference between the anode and the cathode. The electrolyte keeps the electrons from going straight from the anode to the cathode within the battery. When the circuit is closed (a wire connects the cathode and the anode) the electrons will be able to get to the cathode (Fig. 2). The common anode materials used in batteries are titanium oxides, graphite, porous carbons, alloys ( $\mathrm{Si}$, $\mathrm{Ge}, \mathrm{Al}, \mathrm{Sn}, \mathrm{Sb}$ etc.), metal oxides and oxysalts, pure metal foils etc. The cathode materials used in batteries are vanadium oxide, molybdenum sulfide, molybdenum oxide, manganese oxide, silicates, $\mathrm{LiCoO}_{2}, \mathrm{LiFePO}_{4}, \mathrm{LiMn}_{2} \mathrm{O}_{4}$ etc. [1-5]. The different types of electrolyte materials based on biopolymer are studied briefly in this review.

\subsection{Preparaton of biopolymer electrolyte}

BPE films reported in this review are prepared by the standard solution cast technique. In a common procedure, biopolymers and the desired amount of salts are weighed separately and dissolved in distilled methanol or any other suitable solvents. The mixtureis stirred for a long time to obtain clear solution and then poured in 
polypropylene/teflon molds under controlled environmental conditions (temperature, relative humidity). The solvent is evaporated slowly at room temperature and a free standing BPE film is obtained. In some instances, biopolymer films are soaked in an electrolyte solution to allow diffusion of ions. The BPE film matrix obtained is characterized by using various techniques $[101,136,137,166]$. The basic organic chemistry and physics that lie behind preparation and working principle of a BPE is summarized in the following section.

\section{Solid biopolymer electrolyte used in electrochemical devices}

\subsection{Development of solid biopolymer electrolytes for electrochemical devices}

Polysaccharides represent the dominant class of biopolymers used in developing efficient electrochemical devices [1-4,2789,101-291]. Some of the widely used polysaccharides are briefly introduced below.

\subsubsection{Agarose/Agar}

Agarose is a linear polymer consisting of alternating beta-Dgalactose and 1, 4-linked 3, 6-anhydro-alpha-L-galactose units [10]. It has very few sulfate groups. The gelling temperature ranges from $32-45^{\circ} \mathrm{C}$, and the melting temperature range is normally 80 $95^{\circ} \mathrm{C}$. Methylation, alkylation and hydroxyalkylation of the polymer chain can change the melting and gelling temperatures [11] Generally agarose/agar are insoluble in cold water, but it swells considerably. However, it can easily dissolve in hot water $\left(\mathrm{H}_{2} \mathrm{O}\right)$ other solvents at temperatures between $95^{\circ}$ and $100{ }^{\circ} \mathrm{C}$ such as DMF (Dimethylformamide), DMSO (Dimethyl sulfoxide), dimethylacetamide (DMAc), Glycol, orthophosphoric acid, (NMP) N-Methyl-2-pyrrolidone etc. Mechanically strong gel with a small amount of agarose can be produced, while maintaining the ionic conductivity of the liquid electrolyte. Agarose shows good ionic conductivity in the order of $10^{-2}-10^{-4} \mathrm{~S} / \mathrm{cm}$. Complex impedance spectroscopy analysis revealed that doping of KI provide additional charge carries (cations/anions) and enhance the overall conductivity. The maximum conductivity reported in literature is around $10^{-2} \mathrm{~S} / \mathrm{cm}[1,7]$.

\subsubsection{Carrageenan}

Carrageenan is obtained from the red seaweeds of the class rhodophyceae. It is a group of linear galactan with ester sulfate content of $15-40 \%(\mathrm{w} / \mathrm{w})$ and containing alternating $(1 \rightarrow 3)-\alpha-\mathrm{D}$ and $(1 \rightarrow 4)-\beta-$ Dgalactopyranosyl (or 3,6-anhydro- $\alpha$-D-galactopyranosyl) linkages. Three types of commercially available carrageenans are $\kappa, 1$, and $\lambda$. Anionic polysaccharides with molecular weight: 100,000-1,000,000, form gels with potassium or calcium ions [6,10,12]. Carrageenan can also easily dissolve in hot water $\left(\mathrm{H}_{2} \mathrm{O}\right)$ even at room temperature. The solubility temperature is between $40^{\circ}$ and $70{ }^{\circ} \mathrm{C}$ in solvents such as DMSO but it is insoluble in ethanol, acetone and some other organic solvents [11]. Ionic conductivity of carrageenan was found in the range of $10^{-7}$ to $10^{-3} \mathrm{~S} / \mathrm{cm}$ in water and DMSO. The highest conductivity achieved for $\kappa$-carrageenan-AN/MOZ-TBP- $\mathrm{I}_{2} / \mathrm{Lil}-\mathrm{Pr}{ }_{4} \mathrm{NI}+\mathrm{I}^{3-}$ is $2.98 \times 10^{-3} \mathrm{~S} / \mathrm{cm}$ at room temperature.

\subsubsection{Alginate}

Alginate is obtained from the brown seaweeds of the class Phaeophyceae, as a structural material. Linear polysaccharide composed of $\beta$-D-mannuronopyranosyl and $\alpha$-L-guluronopyranosyl units. The units occur in $\mathrm{M}$ blocks (containing solely mannuronopyranose residues), G blocks (containing solely guluronopyranose residues), or MG blocks. Ratio of G-, M-, and MGblocks affects the gel strength, calcium reactivity, and other properties [10]. Alginate form gels with calcium ions. Alginate with high G-blocks results in greater gel strength. Alginate with high M-blocks is more calcium tolerant and less likely to have problem with syneresis. It dissolves slowly in water, forming a viscous solution, but is insoluble in ethanol and ether [12]. Gel polymer electrolytes (GPEs) based on sodium alginate plasticized with glycerol containing either $\mathrm{CH}_{3} \mathrm{COOH}$ or $\mathrm{LiClO}_{4}$. The membranes showed ionic conductivity results of $3.1 \times 10^{-4} \mathrm{~S} / \mathrm{cm}$ for the samples with $\mathrm{LiClO}_{4}$ and $8.7 \times 10^{-5} \mathrm{~S} / \mathrm{cm}$ for the samples with $\mathrm{CH}_{3} \mathrm{COOH}$ at room temperature. Results obtained indicate that alginate-based GPEs can be used as electrolytes in electrochemical devices.

\subsubsection{Pectin}

Pectin is found in all land-based plants as a structural material. Commercial pectin is extracted from citrus peel, apple pomace, sugar beet, or sunflower heads. A linear chain of galacturonic acid units has molecular weight about 110,000-150,000. Pectins are soluble in pure water. Monovalent cation (alkali metal) salts of pectinic and pectic acids are usually soluble in water; di- and trivalent cations salts are weakly soluble or insoluble [12]. The plasticized pectin and $\mathrm{LiClO}_{4}$-based gel electrolytes were prepared and analyzed by spectroscopic, thermal, structural, and microscopic analyses. The best ionic conductivity values of $2.536 \times 10^{-2} \mathrm{~S} / \mathrm{cm}$ were obtained at room temperature for the composition based on diethanolamine modified pectin (DAP) and glutaraldehyde (GA) dissolved in pectin based biopolymer electrolyte [133].

\subsubsection{Cellulose}

Cellulose is the most abundant polymer available worldwide. Cellulose is composed of polymer chains consisting of unbranched $\beta(1 \rightarrow$ 4) linked D-glucopyranosyl units (anhydroglucose unit). Nowadays, there are various procedures for extraction of cellulose microfibrils like pulping methods, acid hydrolysis, steam explosion, etc. [11-14]. The samples of HEC (hydroxyethylcellulose) plasticized with glycerol and addition of lithium trifluoromethane sulfonate $\left(\mathrm{LiCF}_{3} \mathrm{SO}_{3}\right)$ salt. The ionic conductivity obtained in the range of $10^{-4}-10^{-5} \mathrm{~S} / \mathrm{cm}$. The best ionic conductivity obtained is $4.68 \times 10^{-2} \mathrm{~S} / \mathrm{cm}$ at room temperature by using lithium bis(trifluoromethanesulfonyl)imide (LiTFSI) doped biopolymer cellulose acetate (CA) matrix in 1-allyl-3-methylimidazolium chloride ([Amim] Cl) [128].

\subsubsection{Plant seeds, plant tuber $\mathcal{E}$ root, cereal starch}

The principal crops used for Starch production include potatoes, corn and rice. In all of these plants, starch is produced in the form of granules, which vary in size and somewhat in composition from plant to plant [6]. The starch granule is essentially composed of two main polysaccharides, amylose and amylopectin with some minor components such as lipids and proteins. Amylose is a linear molecule of $(1 \rightarrow 4)$-linked $\alpha$-D-glucopyranosyl units and molecular weights ranging from $10^{5}$ to $10^{6} \mathrm{~g} \mathrm{~mol}^{-1}$ [12] (Fig. 2). Amylopectin is a highly branched molecule composed of chains of $\alpha$-D-glucopyranosyl residues linked together mainly by $(1 \rightarrow 4)$-linkages but with $(1 \rightarrow 6)$ linkages at the branch points and having molecular weights ranging from $10^{6}$ to $10^{8} \mathrm{~g} \mathrm{~mol}^{-1}$. Amylose is water soluble but Amylopectin is insoluble in cold water and swells in it thereby giving rise to a thick paste upon boiling with water.It is a biopolymer contains about 23\% starch (20-25\% amylose and 75-80\% amylopectin). It is clear that adding KI in Arrowroot matrix enhances the ionic conductivity and conductivity maxima were obtained by doping NaI and KI concentration where conductivity value approaches at $6.7 \times 10^{-4}$ and $1.04 \times 10^{-4} \mathrm{~S} / \mathrm{cm}$, respectively [166,167]. Adding (Glycerol $\left.+\mathrm{LiCl}\right)$ and $\mathrm{KI}$ in Sago Palm matrix enhances the ionic conductivity and conductivity maxima was obtained by adding $\mathrm{LiCl}$ where conductivity value approachedto $10^{-3} \mathrm{~S} / \mathrm{cm}$ with $\mathrm{LiCl}[38]$ and $3.4 \times 10^{-4} \mathrm{~S} / \mathrm{cm}$ for KI $[136,137]$. Potato starch with $\mathrm{NH}_{4} \mathrm{I}$ based biopolymer electrolyte 
prepared by solution casting technique gives best ionic conductivity of $\sim 2.4 \times 10^{-4} \mathrm{~S} / \mathrm{cm}[163]$.

Corn starch-based biopolymer electrolytes have been prepared by solution casting technique. Lithium hexafluorophosphate (LiPF6) and 1-butyl-3-methylimidazolium trifluoromethanesulfonate (BmImTf) were used as lithium salt and ionic liquid, respectively [142]. In anotherstudyionic liquid, 1-butyl-3-methylimidazolium hexafluorophosphate $\left(\mathrm{BmImPF}_{6}\right)$ was doped into the corn based biopolymer matrix and maximum ionic conductivity of $1.47 \times 10^{-4} \mathrm{~S} / \mathrm{cm}$ was reported for this system. Biopolymer blend electrolytes based on corn starch and chitosan doped with ammonium iodide $\left(\mathrm{NH}_{4} \mathrm{I}\right)$ was also prepared. A polymer blend at $80 \mathrm{wt} \%$ starch and $20 \mathrm{wt} \%$ chitosan was found to be the most amorphous blend. The highest ionic conductivity achieved at room temperature is $3.04 \times 10^{-4} \mathrm{~S} / \mathrm{cm}$ with $\mathrm{NH}_{4} \mathrm{I}$ [139]. The overall best ionic conductivity $\sim 10^{-5} \mathrm{~S} / \mathrm{cm}$ is reported by using $\mathrm{N}, \mathrm{N}-\mathrm{di}$ methylacetamide (DMAc) along with lithium chloride ( $\mathrm{LiCl}$ ) doped corn based biopolymer [151].

Rice starch doped with Lil was prepared using solution casting method, at room temperature the highest ionic conductivity achieved was around $4.7 \times 10^{-5} \mathrm{~S} / \mathrm{cm}$ [158]. Tapioca is a polymer containing heteroatoms in their structure. Hence, they can interact with protons or lithium ions leading to ionic conduction. Among different natural polymers, starch-based bio polymer electrolyte presentgood opto-electrochemical characteristics and can be applied to electrochemical devices. The ionic conductivity results obtained for these bio polymer electrolytes varied from $10^{-6} \mathrm{~S} / \mathrm{cm}$ to $10^{-4} \mathrm{~S} / \mathrm{cm}$ at room temperature, Conductivity reaches to $8.1 \times 10^{-3} \mathrm{~S} / \mathrm{cm}$ for cassava doped with lithium perchlorate. The amount of Acetic acid and $\mathrm{NH}_{4} \mathrm{NO}_{3}$ was found to influence the proton conduction. Wheat can easily dissolve in Acetic acid and room temperature conductivity was found in the order of $10^{-5} \mathrm{~S} / \mathrm{cm}$ to $10^{-4} \mathrm{~S} / \mathrm{cm}$. The common starch based biopolymer electrolytes used in electrochemical devices are shown in Table 1.

\subsubsection{Chitin and chitosan}

Chitosan is a linear polysaccharide consisting of $\beta(1-4)$ linked D-glucosamine with randomly located $\mathrm{N}$-acetylglucosamine groups depending upon the degree of deacetylation of the polymer. Chitin basically found in the shells of crabs, lobsters, shrimps and insects. Chitosan is the deacylated derivative of chitin. Chitin is insoluble in its native form but chitosan, is water soluble. Chitosan is soluble in weakly acidic solutions resulting in the formation of a cationic polymer with a high charge density and can therefore form polyelectrolyte complexes with wide range of anionic polymers. Chemical modification of chitosan can significantly affect its solubility and degradation rate [10-14].

The electrical properties of polymer electrolytes based on chitosan complexed with lithium and ammonium salts have been reported [177-179,196,197,200]. Conductivities of the order of $10^{-6} \mathrm{~S} / \mathrm{cm}$ at room temperature were reported for chitosan with poly (ethylene oxide) PEO blends and doped with LiTFSI salt [101] and also for the complex formed by chitosan, poly (aminopropylsiloxane) (pAPS) and $\mathrm{LiClO}_{4}$ [105]. Conductivity ranges from
$10^{-5}$ and $10^{-4} \mathrm{~S} / \mathrm{cm}$ were reported for proton-conducting polymer electrolytes, based on chitosan and ammonium salts $\left(\mathrm{NH}_{4} \mathrm{NO}_{3}\right.$ and $\left.\mathrm{NH}_{4} \mathrm{CF}_{3} \mathrm{SO}_{3}\right)[183,188]$ and this value is in the range of $10^{-6}-10^{-4} \mathrm{~S} / \mathrm{cm}$ for chitosan and $\mathrm{\kappa}$-carrageenan containing ammonium nitrate-based film $[18,19]$. $\mathrm{LiMn}_{2} \mathrm{O}_{4}$ doped biopolymer based chitosan with carbon has reported biopolymer-in-salt based electrolyte achieves the best ionic conductivity; $3.9 \times 10^{-3} \mathrm{~S} / \mathrm{cm}$ at room temperature [210].

\subsubsection{Gum Arabic}

A gummy exudate obtained from Acacia trees with molecular weight about 250,000 is highly soluble with low viscosity even at $40 \%$ concentration. Gum Arabic, e.g. Acacia arabica, Acacia babul, exhibits a conductivity of approximately $1.5 \times 10^{-6} \mathrm{~S} / \mathrm{cm}$ after drying. Gum Arabica produces salt complexes with inorganic materials like $\mathrm{FeSO}_{4},\left[\mathrm{~K}_{2} \mathrm{SO}_{4}, \mathrm{Al}_{2}\left(\mathrm{SO}_{4}\right)_{3}, 24 \mathrm{H}_{2} \mathrm{O}\right]$, $\mathrm{LiClO}_{4}$, iodine etc. and functions as a proton conductor through hydronium ions $\mathrm{H}_{3} \mathrm{O}^{+}[69]$.

\subsubsection{Gum Tragacanth}

Gum Tragacanth is an exudate of Astragalus, a perennial short brush in Asia. It is slightly acidic and found as $\mathrm{Ca}, \mathrm{Mg}$, or Na salts. It contains neutral highly branched arabinogalactan and tragacanthic acid (linear $(1 \rightarrow 4)$-linked $\alpha$-D-galacturonopyranosyl units, with some substitutions). It is highly viscous with some emulsification properties. Highest conductivity reported for $\mathrm{NaOH}$ based biopolymer is $88.8 \times 10^{-3} \mathrm{~S} / \mathrm{cm}$ at room temperature [170].

\subsubsection{Xanthan gum}

Xanthan gum is prepared through culturing Xanthomonas campestris, a single-cell organism producing gum as protective coating. A trisaccharide side chain is attached to alternate D-glucosyl units at the O-3 position. The side chain consists of a D-glucuronosyl unit between two D-mannosyl units. Molecular weight is about $2,000,000-3,000,000$. Its viscosity is stable at a wide temperature and $\mathrm{pH}$ range. Among the systems studied, i.e. Gum Xanthan+PVP, Gum tragacanth + PVP and Gum Acacia + PVP, Gum Acacia + PVP presents better compatibility as it has stronger intermolecular interaction. In the same manner, among Gum Xanthan + PEG, Gum Acacia + PEG and Gum tragacanth + PEG systems, Gum Tragacanth + PEG has better compatibility [171].

\subsubsection{Gellan gum}

Gellan gum is prepared by culturing Pseudomonas elodea and composed of a four-sugar repeating sequence containing one D-glucuronopyranosyl, two D-glucopyranosyl, and one L-rhamnopyranosyl unit. Its molecular weight is about 1,000,000$2,000,000$. It requires either monovalent or divalent cations to form a gel [10-14]. The ionic conductivity measurements revealed that the ionic conductivity of the Gellan gum doped with $40 \mathrm{wt} \%$ of (lithium trifluoromethanesulfonate) $\mathrm{LiCF}_{3} \mathrm{SO}_{3}$ electrolyte varies with the salt concentration reaching the highest conductivity value of $5.4 \times 10^{-4} \mathrm{~S} / \mathrm{cm}$ at room temperature [173]. When doped

Table 1

Conductivity values of some of the starch based biopolymer electrolytes reported in literature.

\begin{tabular}{|c|c|c|c|c|c|c|c|}
\hline Starch & Amylose (\%) & Starch (\%) & Type & Gelatinization temperature range $\left[{ }^{\circ} \mathrm{C}\right]$ & Dispersoids & Conductivity (S/cm) & Ref. \\
\hline Arrowroot & 20.5 & 84 & Root & $70-75$ & $\mathrm{KI}$ & $1.04 \times 10^{-4}$ & {$[136,137]$} \\
\hline Corn & 28 & $31-50$ & Cereal & $62-72$ & LiI & $1.83 \times 10^{-4}$ & {$[146]$} \\
\hline Pea & 27 & 40 & Legume & $60-75$ & - & - & - \\
\hline Potato & 20 & 65 & Tuber & $59-68$ & $\mathrm{NaI}$ & $1.3 \times 10^{-4}$ & {$[161,162]$} \\
\hline Rice & 18.5 & 87 & Grain & - & LiI & $4.68 \times 10^{-5}$ & {$[158,159]$} \\
\hline Sago & 25.8 & 84 & Root & $70-72$ & KI & $3.4 \times 10^{-4}$ & {$[166]$} \\
\hline Tapioca/ Cassava & 16.7 & 84 & Root & 58.-70 & Li salt & $10^{-6}$ to $10^{-4}, 8.1 \times 10^{-3}$ & - \\
\hline Wheat & 26 & 25 & Cereal & $58-64$ & $\mathrm{CH}_{3} \mathrm{COOH}$ & $10^{-5}$ to $10^{-4}$ & - \\
\hline
\end{tabular}


with Lil, it exhibit ionic conductivity of $3.8 \times 10^{-4} \mathrm{~S} / \mathrm{cm}$ at room temperature [174]. To achieve good ionic conductivity, plasticizers such as, glycerol, ethylene glycol, ethylene carbonate, propylene carbonate are used, and adding lithium salts of $\mathrm{LiClO}_{4}, \mathrm{LiBF}_{4}$, $\mathrm{LiCF}_{3} \mathrm{SO}_{3}, \mathrm{LiI} / \mathrm{I}_{2}$ or acetic acid promoted the proton conduction [173-175].

\subsubsection{Carboxymethyl cellulose (CMC)}

Carboxymethyl cellulose (CMC) is prepared by soaking cellulose in aqueous sodium hydroxide and reacting with monochloroacetic acid [10,11]. Carboxymethyl cellulose doped with Lithium perchlorate and plasticizer polycarboxylate based transparent solution of $\mathrm{CMC} / \mathrm{LiClO}_{4} / \mathrm{PC}$ is reported and ionic conductivity of the biopolymer electrolyte is found to be $2 \times 10^{-4} \mathrm{~S} / \mathrm{cm}$. In another system, oleic acid based biopolymer electrolyte and $\mathrm{NH}_{4} \mathrm{Br}$ based electrolyte achieved ionic conductivity values of $2.11 \times 10^{-5}$ and $1.12 \times 10^{-4} \mathrm{~S} / \mathrm{cm}$, respectively [213,218]. CMC is doped with different concentration of $\mathrm{DTAB} / \mathrm{EC}$ via solution casting technique. The highest ionic conductivity, $\sigma$, was found to be $2.37 \times 10^{-3} \mathrm{~S} / \mathrm{cm}$ at room temperature [216].

\subsection{Gelatinization and ion transport mechanism in biopolymer electrolytes}

\subsubsection{Gelatinization}

Polysaccharides can also be classified according to their ionic character (neutral, anionic, cationic). As a result of which they bring different properties and chemical functionalities to the biocomposites. The polysaccharides indicated in Table 2 derive from natural sources, hence presenting advantages in terms of biodegradability, low-toxicity and low cost. Polysaccharide is an emerging branch of polymer which acts as a novel electrolyte in electrochemical devices $[11,15]$. Polysaccharides have been used as composite matrices due to several characteristics of relevance for biological and electrochemical device applications. Variety of structures in biopolymers imparts different properties in them. The biopolymers which are most commonly used in developing electrochemical devices are summarized in Table 2. In biopolymers the hydroxyl groups of sugar rings allow the structure to substitute easily with other functional groups. Differences in the sugar composition and functional group substitution, effect on the three-dimensional packing of the polysaccharides and their interactions with other polymers or salts. Polysaccharides having extensive hydrogen bonding appear to be more conductive than that of the ones with a few hydrogen bonds and ion mobility of the electroactive material depends on the crystallinity of the polymer. When a dopant salt is introduced in to the matrix, the dominant energetic barrier experienced by the cation in conduction, is given by the dissociation of the alkali itself. The material can be both ionically and electronically conducting. However, in most biopolymers (polysaccharides) conduction is mainly due to the movement of single ionic specie. The ion conduction mechanism could be clearly understood in a common biopolymer electrolyte i.e. starch. Biopolymer starch is the plasticized starch that has been processed (typically using heat and pressure) to destroy the crystalline structure and to form an amorphous thermoplastic starch. Thermoplastic starch processing typically involves an irreversible molecular organization termed gelatinization and affected by starch-water interactions [7,12]. Fig. 3 summarizes the gelatinization process. Pure biopolymer starch presents a compact nature (Fig. 3a) made up of amylose (linear) and amylopectin (branched) molecules. In aqueous media, the crystallinity is affected and helices are disturbed (Fig. 3b) [7] and upon heating, swelling of the granules is accelerated that allows the amylose diffusion out of the granule (Fig. 3c).

\subsubsection{Ion transport mechanism}

The common ion transport in a biopolymer-salt complex can be understood using agarose biopolymer: KI polymer electrolyte in which both cation $\left(\mathrm{K}^{+}\right)$and anion $\left(\mathrm{I}^{-}\right)$play dominant roles.

Table 2

Source, dominant functional group and physical structure of some biopolymers commonly used in electrochemical devices.

\begin{tabular}{|c|c|c|c|c|c|}
\hline Source & Biopolymer & Functional groups & Film type & Structure & Ref. \\
\hline Marine red Algae & Agarose/ Agars & $\mathrm{OH}$ & Gel & Linear & [18] \\
\hline Red seaweeds & Carrageenans & $\mathrm{OH}, \mathrm{OSO}_{3}^{-}$ & Gel & Linear & [19] \\
\hline Brown algae & Alginate & $\mathrm{OH}, \mathrm{COO}^{-}$ & Gel & Linear & [20] \\
\hline \multirow[t]{2}{*}{ Plant cell wall } & Cellulose & $\mathrm{OH}$ & Gel & Linear & [21] \\
\hline & Pectin & $\mathrm{OH}, \mathrm{COO}^{-}$ & Gel & Linear & [21] \\
\hline \multirow[t]{2}{*}{ Derived } & Carboxymethyl Cellulose & $\mathrm{OH}, \mathrm{COO}^{-}$ & Thickening/viscosity agents & Linear & {$[21]$} \\
\hline & Methylcellulose (MC) & $\mathrm{OH}, \mathrm{COO}^{-}$ & Gel/ Thickening/viscosity agents & Linear & [21] \\
\hline \multirow[t]{6}{*}{ Plant seeds/cereal starch } & Sago Starch & $\mathrm{OH}$ & Thickening/viscosity agents & Linear/Branch-on-branch & {$[22]$} \\
\hline & Corn Starch & $\mathrm{OH}$ & Thickening/viscosity agents & Linear/Branch-on-branch & [22] \\
\hline & Pea Starch & $\mathrm{OH}$ & Thickening/viscosity agents & Linear/Branch-on-branch & [22] \\
\hline & Rice Starch & $\mathrm{OH}$ & Thickening/viscosity agents & Linear/Branch-on-branch & {$[22]$} \\
\hline & Wheat Starch & $\mathrm{OH}$ & Thickening/viscosity agents & Linear/Branch-on-branch & [22] \\
\hline & Oats Starch & $\mathrm{OH}$ & Thickening/viscosity agents & Linear/Branch-on-branch & [22] \\
\hline \multirow[t]{2}{*}{ Plant tuber \& root } & Potato Starch & $\mathrm{OH}$ & Thickening/viscosity agents & Linear/Branch-on-branch & [22] \\
\hline & Tapioca/Arrowroot Starch & $\mathrm{OH}$ & Thickening/viscosity agents & Linear/Branch-on-branch & [22] \\
\hline Plant exudates/Acacia trees & Gum Arabic & $\mathrm{OH}, \mathrm{COO}^{-}$ & Thickening/viscosity agents & Branch-on-branch & [23] \\
\hline Plant exudates & Gum Tragacanth & $\mathrm{OH}, \mathrm{COO}^{-}$ & Thickening/viscosity agents & Short branched & \\
\hline \multirow[t]{2}{*}{ Microorganism } & Xanthan Gum & $\mathrm{OH}, \mathrm{COO}-$ & Gel & Short branched & \\
\hline & Gellan Gum & $\mathrm{OH}, \mathrm{COO}-$ & Gel & Linear & \\
\hline \multirow[t]{2}{*}{ Shelfish \& fungi cell wall/ Insects } & Chitin & $\mathrm{OH}, \mathrm{NH}_{3}{ }^{+}$ & Gel & Liner & {$[24]$} \\
\hline & Chitosan & $\mathrm{OH}, \mathrm{NH}_{3}^{+}$ & Gel & Liner & [24] \\
\hline
\end{tabular}


(a)

(b)

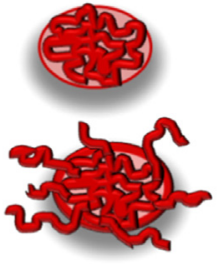

(c)

(d)

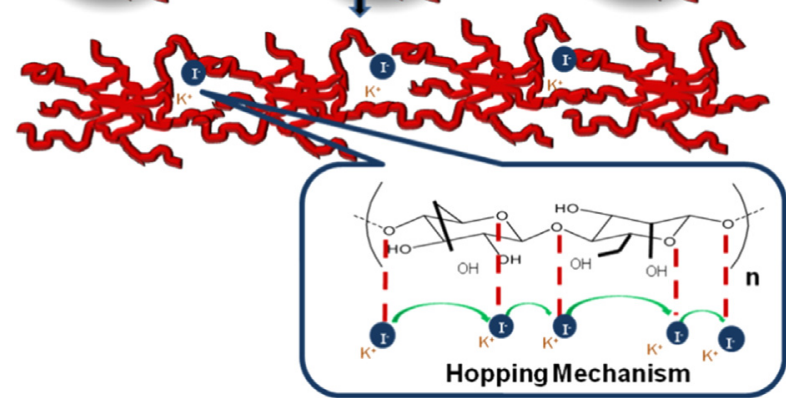

Fig. 3. Common gelatinization process occur in biopolymers (polysaccharides a, b, and c) while common ion transport mechanism in starch-KI biopolymer-salt complex (d).

Adding dispersoids (KI) in biopolymer matrix may enhance amorphous region. The etheric oxygen can easily associate with $\mathrm{K}^{+}$as similar to the other systems reported on PEO based polymer electrolytes $[1,2]$. This weak intraction can be dissociated under the influence of an electric field and together with $\mathrm{I}^{-}, \mathrm{K}^{+}$ions can hop consistently at the coordinating side of the biopolymer structure. Increasing the $\mathrm{K}^{+}$and $\mathrm{I}^{-}$concentration in the media will increase the number of charge carriers and hence the conductivity. The ionic hopping mechanism is demonstrated in Fig. 3d and maybe applied in biopolymer matrix with different alkali salts [1-4].

\subsection{Dye sensitized solar cell using solid biopolymer electrolyte}

The primary aim of development of solid polymer electrolyte is to avoid the disadvantages caused by liquid electrolyte. Biopolymer electrolytes are free from leakage, corrosion and more stable. The moderate conductivity and other advantageous properties make them suitable candidates for DSSCs. The photovoltaic parameters of polysaccharides with various salts (like NaI, KI and $\mathrm{NH}_{4} \mathrm{I}$ etc) are reported in literature and tabulated in Table 3. As expected, the most efficient biopolymer electrolyte based DSSCs contain $\mathrm{I}^{-} / \mathrm{I}^{3-}$ redox couple $[101-117,136,137,160,166,178-181]$.

\subsection{Batteries using biopolymer electrolytes}

As already mentioned earlier an efficient battery needs electrolytes with high ionic conductivity $[1,29,30,33,226]$. Solid polymer electrolytes (SPEs) have been widely examined to substitute conventional liquid electrolytes because of their attractive properties, such as ability to eliminate problems of corrosive solvent leakage, wide electrochemical stability range, light weight, ease of processability and excellent thermal stability as well as low volatility $[225,226]$. The most commonly studied polymer electrolytes for batteries are high molecular weight polyethylene oxide (PEO) complexed with Li salts [2]. PEO qualifies as a host polymer for electrolytes because of its high solvating power for lithium salts and compatibility with lithium electrode [227]. However, one of the major drawbacks of PEO-based solid polymer electrolytes is their low ionic conductivity $\left(10^{-7}-10^{-8} \mathrm{~S} / \mathrm{cm}\right)$ at ambient temperature, which limits their practical applications [228-230].

Most of SPEs are based on hydroxethyl cellulose [231], starch [232], chitosan [233-235], agar-agar [236], pectin [237], and gelatin [238] etc., wherein the ionic conductivity has been reported in the order of $10^{-4} \mathrm{~S} / \mathrm{cm}$ at room temperature.

Cellulose constitutes are the most abundant, renewable polymer source available worldwide today. It is principally used as construction material, in the form of wood or as textile fiber, such as cotton, or in the form of paper and board [239]. Cellulose exists in many forms from micrometric cellulose fibers to nanocellulose. Over the last decade, nanocellulose has attracted an ever increasing attention for the production of cellulose based nanocomposite materials, due to their high strength and stiffness combined with low weight, biodegradability and renewability [240]. Recently, cellulose and its derivatives have been successfully applied in rechargeable batteries for the production of electrodes, separators or as reinforcing agents in solid polymer electrolytes [241]. Samsudin et al. [242] investigated the use of CMC based biopolymer electrolyte complexed with $\mathrm{NH}_{4} \mathrm{Br}$ for the application of rechargeable proton battery. The highest ionic conductivity of the $\mathrm{CMC}-\mathrm{NH}_{4} \mathrm{Br}$ BPE obtained at room temperature is $1.12 \times 10^{-4} \mathrm{~S}$ $\mathrm{cm}^{-1}$ and ionic transference number was reported to be $\sim 0.98$ for this system. Linear sweep voltammetry results revealed that this BPE is electrochemically stable up to $1.42 \pm 0.01 \mathrm{~V}$ and suitable for proton battery application. The cell potential of proton battery is $1.52 \mathrm{~V}$ and showed good rechargeability.

The biopolymer CMC complexed with $\mathrm{CH}_{3} \mathrm{COONH}_{4}$ electrolyte has been reported the best conductivity value of $5.77 \times 10^{-4} \cdot \mathrm{S} \cdot \mathrm{cm}^{-1}$ for the system containing $20 \mathrm{wt} \%$ of $\mathrm{CH}_{3} \mathrm{COONH}_{4}$ at ambient temperature. The electrochemical stability of this system is achieved up to $\sim 2.5 \mathrm{~V}$ and suitable for electrochemical device applications [243]. Ramesh et. al [244] has been studied the effect 1-allyl-3-methylimidazolium chloride [(AMIM]Cl] on cellulose acetate (CA) complexed with LiTFS biopolymer electrolyte. The sample composition of CA:LiTFSI:[AMIM] $\mathrm{Cl}$ (14 wt\%:6 wt\%:80 wt\%) exhibits the highest ionic conductivity of $1.75 \times 10^{-3} \mathrm{~S} \mathrm{~cm}^{-1}$ at room temperature. The collective data of batteries using BPE are tabulated in Tables 4 and 5.

The crops used for starch production include tapioca, wheat, potatoes, corn and rice. Starch is extracted in the form of granules, which vary in composition of amylase and amylopectin from plant to plant [6]. Starch attracts scientists because of its rich variety and abundance in nature. A solid BPE based on amylopectin-rich starch is plasticized with glycerol and contain $\mathrm{LiClO}_{4}$. The highest ionic conductivity reported from this medium is $1.1 \times 10^{-4} \mathrm{~S} / \mathrm{cm}$ at $30^{\circ} \mathrm{C}$. The ionic conductivity as a function of time for amylopectin-rich starch plasticized with $30 \mathrm{wt} \%$ of glycerol and containing $[\mathrm{O}] /[\mathrm{Li}]=10$ showed conduction stability over 6 months $\left(\sigma \sim 3.01 \times 10^{-5} \mathrm{~S} \mathrm{~cm}^{-1}\right)$. These results show that it has the potential to meet all the conditions required by optical and electronic devices which use an electrolyte layer [265]. Lopes et al. investigated the NMR and conductivity results of solid electrolyte systems based on amylopectin rich starch plasticized with glycerol and containing $\mathrm{LiClO}_{4}$. The samples were prepared with salt concentration $[\mathrm{O}] /[\mathrm{Li}]=6$ and 8 and plasticized with $30 \%$ of glycerol, having ionic conductivities of about $5 \times 10^{-5} \mathrm{~S} \mathrm{~cm}^{-1}$ at room temperature. The cation-proton interaction in this system is smaller than that of the grafted systems. The low temperature corresponding to the ${ }^{7} \mathrm{Li}$ spin-lattice relaxation rate maximum indicated that the lithium has a relatively high mobility in the plasticized electrolytes, whereas the starch acts as a polymer matrix for the electrolyte. The results of the BPE based on amylopectin rich starch, plasticized with glycerol and containing lithium salt can be potentially useful for SPE applications [266].

Recently, Navaratnam et al. [267] studied the transport mechanism of chitosan based biopolymer electrolytes. They studied the chitosan-ethylene carbonate/propylene carbonate (chitosan$\mathrm{EC} / \mathrm{PC})$ system with lithium acetate $\left(\mathrm{LiCH}_{3} \mathrm{COO}\right)$ and lithium triflate $\left(\mathrm{LiCF}_{3} \mathrm{SO}_{3}\right)$ as salts. The room temperature conductivity of the sample were found to be $6.1 \times 10^{-7} \mathrm{~S} / \mathrm{cm}$ for chitosan system containing lithium acetate salt and $5.0 \times 10^{-6} \mathrm{~S} / \mathrm{cm}$ for chitosan 
Table 3

Status of dye sensitized solar cell (DSSC), battery and other electrochemical devices using solid biopolymer electrolyte.

\begin{tabular}{|c|c|c|c|c|c|}
\hline Biopolymer & Additive & $\sigma(\mathrm{S} / \mathrm{cm})$ & Unit & Device & References \\
\hline \multirow[t]{21}{*}{ Agarose/Agars } & KI & $9.02 \times 10^{-3}$ & $0.54 \%$ & DSSC & {$[101]$} \\
\hline & Lil & $3.98 \times 10^{-3}$ & - & DSSC & {$[102]$} \\
\hline & $\mathrm{NH}_{4} \mathrm{I}$ & $4.89 \times 10-3$ & $0.008 \%$ & DSSC & [103] \\
\hline & $\mathrm{NaI}$ & $12.41 \times 10^{-4}$ & - & - & {$[104]$} \\
\hline & 1-allyl-3-ethylimidadolium iodide & - & $5.89 \%$ & DSSC & [105] \\
\hline & 1-allyl-3-ethylimidadolium iodide & - & $7.43 \%$ & DSSC & {$[106]$} \\
\hline & DMSO/PC-(MPII) & $14.2 \times 10^{-3}$ & $1.97 \%$ & DSSC & {$[107]$} \\
\hline & DMSO/4EG-(MPII) & $4.4 \times 10^{-3}$ & $1.38 \%$ & DSSC & {$[107]$} \\
\hline & DMSO/3EG-(MPII) & $4.6 \times 10^{-3}$ & $1.39 \%$ & DSSC & {$[107]$} \\
\hline & DMSO/PG-(MPII) & $6.2 \times 10^{-3}$ & $1.06 \%$ & DSSC & {$[107]$} \\
\hline & Pure DMSO-(MPII) & $5.0 \times 10^{-3}$ & $1.15 \%$ & DSSC & {$[107]$} \\
\hline & Polysorbate $80 / \mathrm{Fe}_{3} \mathrm{O}_{4}$ nanoparticles & $2.98 \times 10^{-3}$ & $1.83 \%$ & DSSC & [108] \\
\hline & PEG $200 / \mathrm{Fe}_{3} \mathrm{O}_{4}$ nanoparticles & $2.88 \times 10^{-3}$ & - & DSSC & [109] \\
\hline & $\mathrm{TiO}_{2}$-modified & $2.66 \times 10^{-3}$ & $1.71 \%$ & DSSC & {$[110]$} \\
\hline & $\mathrm{Co}_{3} \mathrm{O}_{4}$-modified & $4.37 \times 10^{-3}$ & $2.11 \%$ & DSSC & [110] \\
\hline & NiO-modified & $3.33 \times 10^{-3}$ & $2.02 \%$ & DSSC & [110] \\
\hline & NMP/LiI & $3.94 \times 10^{-4}$ & $4.14 \%$ & DSSC & {$[111,112]$} \\
\hline & NMP/LiI/nanoparticle $\mathrm{TiO}_{2}$ & $4.4 \times 10^{-4}$ & $4.74 \%$ & DSSC & {$[112]$} \\
\hline & 1-alkyl-3-methyl-imidazolium salts & - & $2.93 \%$ & DSSC & [113] \\
\hline & Acetic acid/glycerol & $1.1 \times 10^{-4}$ & - & - & {$[114]$} \\
\hline & 1-ethyl-3-methylimidazolium acetate & $2.35 \cdot 10^{-5}$ & - & - & {$[115]$} \\
\hline \multirow[t]{5}{*}{ Carrageenans } & 3-methyl-2-oxazolidinone & - & $6.87 \%$ & DSSC & {$[116]$} \\
\hline & AN/MOZ- TBP- $\mathrm{I}_{2} / \mathrm{LiI}-\mathrm{Pr}_{4} \mathrm{NI}+\mathrm{I}^{3-}$ & $2.92 \times 10^{-3}$ & $6.87 \%$ & DSSC & [117] \\
\hline & Chitosan + carrageenan & $1.38 \times 10^{-6}$ & - & - & [118] \\
\hline & Chitosan + carrageenan $+\mathrm{NH}_{4} \mathrm{NO}_{3}$ & $2.39 \times 10^{-4}$ & 13to18.5 $\mathrm{F} \mathrm{g}^{-1}$ & EDLCs & {$[118]$} \\
\hline & Chitosan + carrageenan $+\mathrm{H}_{3} \mathrm{PO}_{4}+\mathrm{PEG}$ & $6.29 \times 10^{-4}$ & $35 \mathrm{Fg}^{-1}$ & EDLCs & [119] \\
\hline \multirow[t]{13}{*}{ Cellulose } & $\mathrm{NH}_{4} \mathrm{NO}_{3}$ & $2.1 \times 10^{-6}$ & - & - & [120] \\
\hline & $\mathrm{NH}_{4} \mathrm{NO}_{3} \mathrm{PEG}$ & - & $31.52 \mathrm{~mA} \mathrm{~cm}^{-2}$ & Fuel cells & {$[121]$} \\
\hline & Cellulose acetate $(\mathrm{CA})+\mathrm{LiBOB}+\mathrm{GBL}$ & $5.36 \times 10^{-3}$ & $4.7 \mathrm{Voc}$ & Battery & {$[122]$} \\
\hline & Cellulose acetate $+\mathrm{TiO}_{2}$ & $1.37 \times 10^{-2}$ & $54.1 \mathrm{~mA} \mathrm{~h}$ & Battery & [123] \\
\hline & Cellulose acetate $+\mathrm{NH}_{4} \mathrm{CF}_{3} \mathrm{SO}_{3}+\mathrm{EC}$ & $\sim 10^{-4}$ & $1.4 \mathrm{Voc}$ & Battery & {$[124]$} \\
\hline & Cellulose acetate electrolyte & - & $22.41 \mathrm{~mA} \mathrm{~h}$ & Battery & [125] \\
\hline & PEO-HPC + LiTFSI & $2.5 \times 10^{-4}$ & $3.65 \mathrm{Voc}$ & Battery & {$[126]$} \\
\hline & $\mathrm{LiCF}_{3} \mathrm{SO}_{3}$ & $5.3 \times 10^{-7}$ & - & - & {$[127]$} \\
\hline & CA-LiTFSI-[Amim] Cl & $4.68 \times 10^{-2}$ & - & - & {$[128]$} \\
\hline & $\mathrm{CA}-\mathrm{NH}_{4} \mathrm{BF}_{4}$ & $2.18 \times 10^{-7}$ & - & - & [129] \\
\hline & $\mathrm{CA}-\mathrm{NH}_{4} \mathrm{BF}_{4}+\mathrm{PEG} 600$ & $1.41 \times 10^{-5}$ & - & - & [129] \\
\hline & CA-LiTFSI-DES & $2.61 \times 10^{-3}$ & - & - & {$[130]$} \\
\hline & BC-TEA & $1.8910^{-5}$ & - & - & [131] \\
\hline \multirow[t]{4}{*}{ Pectin } & Amidated pectin + Glutaraldehyde (GA) & $1.098 \times 10^{-3}$ & - & - & {$[132]$} \\
\hline & $\mathrm{DAP}+$ glutaraldehyde $(\mathrm{GA})$ & $2.536 \times 10^{-2}$ & - & - & [133] \\
\hline & $\mathrm{LiClO}_{4}$ & $4.7 \times 10^{-4}$ & - & - & {$[134]$} \\
\hline & $\mathrm{KCl}$ & $1.45 \times 10^{-3}$ & - & - & {$[135]$} \\
\hline \multirow[t]{2}{*}{ Sago Starch } & KI & $3.4 \times 10^{-4}$ & $0.57 \%$ & DSSC & {$[136,137]$} \\
\hline & Glycerol+ $+\mathrm{LiCl}$ & $10^{-3}$ & - & - & [138] \\
\hline \multirow[t]{21}{*}{ Corn Starch } & Starch - chitosan-NH4I & $3.04 \times 10^{-4}$ & - & - & [139] \\
\hline & $\mathrm{NH}_{4} \mathrm{Br}$ & $5.57 \times 10^{-5}$ & - & - & {$[140]$} \\
\hline & $\mathrm{NH}_{4} \mathrm{Br}+$ Glycerol & $1.80 \times 10^{-3}$ & - & - & [141] \\
\hline & $\mathrm{LiPF}_{6}+\mathrm{BmImTf}$ & $3.21 \times 10^{-4}$ & - & - & {$[142]$} \\
\hline & LiOAC & $2.07 \times 10^{-5}$ & $33.31 \mathrm{~F} \mathrm{~g}^{-1}$ & EDLC & {$[143]$} \\
\hline & Glycerol- LiOAc & $1.04 \times 10^{-3}$ & - & - & [143] \\
\hline & $\mathrm{LiPF}_{6}-\mathrm{BmImTf}$ at $80^{\circ} \mathrm{C}$ & $6.00 \times 10^{-4}$ & - & - & {$[144]$} \\
\hline & $\mathrm{LiClO}_{4}$ & $1.28 \times 10^{-4}$ & - & - & {$[145]$} \\
\hline & LiTFSI-DES(Choline chloride \& urea) & $1.04 \times 10^{-3}$ & - & - & {$[146]$} \\
\hline & LiI & $1.83 \times 10^{-4}$ & - & - & {$[147]$} \\
\hline & Lil- Glycerol & $9.56 \times 10^{-4}$ & - & - & [147] \\
\hline & LiTFSI-[Amim] Cl & $4 \cdot 18 \times 10^{-2}$ & - & - & {$[148]$} \\
\hline & LiTFSI-[Amim] Cl & $5.68 \times 10^{-2}$ & - & - & [149] \\
\hline & $\mathrm{LiPF}_{6}-\mathrm{BmImPF}_{6}$ & $1.47 \times 10^{-4}$ & - & - & [149] \\
\hline & $\mathrm{LiClO}_{4}-\mathrm{SiO}_{2}$ & $1.23 \times 10^{-4}$ & - & - & {$[150]$} \\
\hline & {$[\mathrm{Amim}] \mathrm{Cl}$} & $10^{-1.6}$ & - & - & {$[151,152]$} \\
\hline & DMAC - $\mathrm{LiCl}$ & $10^{-0.5}$ & - & - & {$[151,153]$} \\
\hline & Glycerol & $10^{-8}$ & - & - & {$[151,154]$} \\
\hline & Glycerol - Carbon black & 7.08 & - & - & {$[151,154]$} \\
\hline & [BMIM]Cl & $10^{-4.6}$ & - & - & {$[155]$} \\
\hline & Starch-Chitosan blend-NH 4 I-Glycerol & $1.28 \times 10^{-3}$ & $1.8-4.0 \mathrm{~F} \mathrm{~g}^{-1}$ & EDLC & {$[156]$} \\
\hline Pea Starch & KI & $2.28 \times 10^{-4}$ & - & - & [157] \\
\hline \multirow[t]{3}{*}{ Rice Starch } & LiI & $4.68 \times 10^{-5}$ & - & - & {$[158,159]$} \\
\hline & Lil-TiO & $2.27 \times 10^{-4}$ & - & - & {$[160]$} \\
\hline & Lil-MPII-TiO2 & $3.63 \times 10^{-4}$ & $0.17 \%$ & DSSC & {$[160]$} \\
\hline Wheat Starch & $\mathrm{CH} 3 \mathrm{COOH}$ (Acetic acid) & $10^{-5}$ to $10^{-4}$ & - & - & - \\
\hline \multirow{4}{*}{ Potato Starch } & $\mathrm{NaI}$ & $1.3 \times 10^{-4}$ & - & - & {$[161,162]$} \\
\hline & $\mathrm{NaClO}_{4}$ & $7.19 \times 10^{-6}$ & - & - & {$[161]$} \\
\hline & $\mathrm{NaSCN}$ & $1.12 \times 10^{-4}$ & - & - & [161] \\
\hline & $\mathrm{NH}_{4} \mathrm{I}$ & $2.4 \times 10^{-4}$ & - & - & [163] \\
\hline
\end{tabular}


Table 3 (continued)

\begin{tabular}{|c|c|c|c|c|c|}
\hline Biopolymer & Additive & $\sigma(\mathrm{S} / \mathrm{cm})$ & Unit & Device & References \\
\hline & Methanol-GA & $2.50 \times 10^{-6}$ & - & - & {$[164]$} \\
\hline & Methanol-GA-NaI & $8.40 \times 10^{-6}$ & - & - & {$[164]$} \\
\hline & Methanol-GA -PEG300-NaI & $1.80 \times 10^{-4}$ & - & - & {$[164]$} \\
\hline & Acetone- GA & $8.80 \times 10^{-6}$ & - & - & {$[164]$} \\
\hline & Acetone- GA- NaI & $3.22 \times 10^{-5}$ & - & - & {$[164]$} \\
\hline & Acetone-GA- PEG300-NaI & $4.30 \times 10^{-5}$ & - & - & {$[164]$} \\
\hline & - & - & $335 \mathrm{Fg}^{-1}$ & EDLC & [165] \\
\hline \multirow[t]{3}{*}{ Arrowroot Starch } & KI & $5.68 \times 10-4$ & $0.63 \%$ & DSSC & [166] \\
\hline & $\mathrm{NaI}$ & $6.7 \times 10^{-4}$ & - & - & {$[167]$} \\
\hline & Chitosan blend $-\mathrm{NH}_{4} \mathrm{NO}_{3}$ & $3.89 \times 10^{-5}$ & - & - & {$[168]$} \\
\hline Gum Arabic & - & $1.5 \times 10^{-6}$ & - & - & [169] \\
\hline Gum Tragacanth & $\mathrm{NaOH}$ & $88.8 \times 10^{-3}$ & - & - & {$[170]$} \\
\hline Xanthan Gum & Water-based thixotropic & - & $4.78 \%$ & DSSC & [171] \\
\hline \multirow[t]{3}{*}{ Gellan Gum } & $\mathrm{LiCF}_{3} \mathrm{SO}_{3}$ & $5.4 \times 10^{-4}$ & - & - & {$[172]$} \\
\hline & LiI & $1.5 \times 10^{-3}$ & - & - & {$[173]$} \\
\hline & Polypyrrole-Gellan gum & - & -0.8 to $+0.4 \mathrm{~V}$ & EDLC & {$[174]$} \\
\hline \multirow{56}{*}{ Chitin/Chitosan } & $\mathrm{NaI}$ & - & $0.13 \%$ & DSSC & [175] \\
\hline & EMImSCN-NaI & $2.60 \times 10^{-4}$ & $0.73 \%$ & DSSC & {$[175]$} \\
\hline & $\mathrm{NH}_{4} \mathrm{SCN}-\mathrm{Al}_{2} \mathrm{TiO}_{5}$ & $2.10 \times 10^{-4}$ & - & - & {$[176]$} \\
\hline & $\mathrm{LiNO}_{3} \mathrm{NH}_{4} \mathrm{I}$ & $2.7 \times 10^{-4}$ & $1.113 \mathrm{~V}$ & Battery & {$[177]$} \\
\hline & $\mathrm{NH}_{4} \mathrm{I}-\mathrm{EC}$. & $3.73 \times 10^{-7}$ & $0.29 \%$ & DSSC & {$[178]$} \\
\hline & $\mathrm{NH}_{4} \mathrm{I}-\mathrm{BMII}$ & $7.34 \times 10^{-6}$ & $0.51 \%$ & DSSC & {$[178]$} \\
\hline & Tartaric- $\mathrm{NH}_{4} \mathrm{I}-\mathrm{BMII}$ & $8.47 \times 10^{-4}$ & $1.24 \%$ & DSSC & {$[178]$} \\
\hline & Tartaric-PEO- $\mathrm{NH}_{4} \mathrm{I}-\mathrm{BMII}$ & $3.02 \times 10^{-4}$ & $0.38 \%$ & DSSC & [179] \\
\hline & Tartaric-Phthaloyl chitosan-NH 4 I-BMII & $5.52 \times 10^{-4}$ & $0.39 \%$ & DSSC & [179] \\
\hline & Tartaric-Phthaloyl chitosan-PEO-NH 4 I-BMII & $5.86 \times 10^{-4}$ & $0.43 \%$ & DSSC & {$[179]$} \\
\hline & PEO blend- $\mathrm{NH}_{4} \mathrm{I}$ & $6.24 \times 10^{-4}$ & $0.46 \%$ & DSSC & [179] \\
\hline & PEO blend-NH ${ }_{4} \mathrm{I}$ (Dye-Sumac/Rhus) & & & & \\
\hline & $\mathrm{NH}_{4} \mathrm{CF}_{3} \mathrm{SO}_{3}$ & $4.32 \times 10^{-6}$ & $0.46 \%$ & DSSC & {$[180]$} \\
\hline & Methylcellulose blend $-\mathrm{H}_{4} \mathrm{CF}_{3} \mathrm{SO}_{3}$ & $1.18 \times 10^{-5}$ & $1.5 \%-$ & DSSC & {$[181]$} \\
\hline & EC-LiOAC & $8.91 \times 10^{-7}$ & - & - & {$[183]$} \\
\hline & NaI & $4.99 \times 10^{-6}$ & - & - & [183] \\
\hline & EMImSCN-NaI & $7.6 \times 10^{-6}$ & $0.13 \%$ & - & {$[184]$} \\
\hline & chitosan-LiOAc-oleic acid & $10^{-5}$ & - & - & {$[185]$} \\
\hline & chitosan, palmitic acid (PA)-LiOAc & $5.5 \times 10^{-6}$ & - & - & {$[186]$} \\
\hline & Corn starch - $\mathrm{NH}_{4} \mathrm{Cl}$-Glycerol & $5.11 \times 10^{-4}$ & - & - & {$[187]$} \\
\hline & $\mathrm{NH}_{4} \mathrm{NO}_{3}$ & $2.53 \times 10^{-5}$ & - & - & {$[188]$} \\
\hline & $\mathrm{NH}_{4} \mathrm{NO}_{3}$-Acetic acid & $1.46 \times 10^{-1}$ & $27.90 \mathrm{~mA} \mathrm{~h}^{-1}$ & Battery & [189] \\
\hline & & - & $3.67 \mathrm{~mW} \mathrm{~cm}^{-2}$ & - & - \\
\hline & $\mathrm{NH}_{4} \mathrm{NO}_{3}$-EC- Acetic acid & $9.93 \times 10^{-3}$ & $8.70 \mathrm{~mW} \mathrm{~cm}^{-2}$ & Battery & [190] \\
\hline & & - & $17.0 \mathrm{~mA} \mathrm{~h}$ & - & - \\
\hline & Polyethylene oxide $-\mathrm{NH}_{4} \mathrm{NO}_{3}$ & $1.02 \times 10^{-4}$ & - & - & [191] \\
\hline & $\mathrm{LiCF}_{3} \mathrm{SO}_{3}$ & $2.75 \times 10^{-5}$ & - & - & [192] \\
\hline & CMC-Chitosan-DTAB & $1.85 \times 10^{-6}$ & - & - & [193] \\
\hline & PVA-Chitosan- $\mathrm{NH}_{4} \mathrm{NO}_{3}$ & $2.07 \times 10^{-5}$ & 1.6 and $1.7 \mathrm{~V}$ & Battery & [194] \\
\hline & PVA-chitosan- $\mathrm{NH}_{4} \mathrm{NO}_{3}$-EC & $1.60 \times 10^{-3}$ & $27.1 \mathrm{Fg}^{-1}$ & EDLC & [195] \\
\hline & PVA- $\mathrm{NH}_{4} \mathrm{I}$ & $1.77 \times 10^{-6}$ & - & - & {$[196]$} \\
\hline & $\mathrm{NH}_{4} \mathrm{I}$ & $3.73 \times 10^{-7}$ & $0.22 \%$ & DSSC & {$[196,197]$} \\
\hline & $\mathrm{NH}_{4} \mathrm{I}-\mathrm{EC}$ & $7.34 \times 10^{-6}$ & $0.18 \mathrm{FF}$ & DSSC DSSC & [197] \\
\hline & $\mathrm{NH}_{4} \mathrm{I}-\mathrm{BMII}$ & $3.43 \times 10^{-5}$ & $0.22 \mathrm{FF}$ & - & [197] \\
\hline & $\mathrm{LiCF}_{3} \mathrm{SO}_{3}-\mathrm{DEC}-\mathrm{EC}$ & $4.26 \times 10^{-5}$ & - & Fuel cell & [198] \\
\hline & $\mathrm{H}_{3} \mathrm{PO}_{4}$ & $5.36 \times 10^{-5}$ & - & Fuel cell & [199] \\
\hline & $\mathrm{H}_{3} \mathrm{PO}_{4}-\mathrm{Al}_{2} \mathrm{SiO}_{5}$ & $1.12 \times 10^{-4}$ & - & Fuel cell & [199] \\
\hline & $\mathrm{H}_{3} \mathrm{PO}_{4}-\mathrm{NH}_{4} \mathrm{NO}_{3}$ & $1.16 \times 10^{-4}$ & - & Fuel cell & [199] \\
\hline & $\mathrm{H}_{3} \mathrm{PO}_{4}-\mathrm{NH}_{4} \mathrm{NO}_{3}-\mathrm{Al}_{2} \mathrm{SiO}_{5}$ & $1.82 \times 10^{-4}$ & - & - & [199] \\
\hline & PEO- LiTFSI & $1.40 \times 10^{-6}$ & - & Battery & [200] \\
\hline & $\mathrm{LiCF}_{3} \mathrm{SO}_{3}-\mathrm{DEC}-\mathrm{EC}$ & $4.26 \times 10^{-5}$ & - & Battery & [201] \\
\hline & $\mathrm{LiCF}_{3} \mathrm{SO}_{3}-\mathrm{PC} / \mathrm{EC}$ & $1.09 \times 10^{-4}$ & - & - & [201] \\
\hline & LiOAC & $2.20 \times 10^{-7}$ & - & - & [202] \\
\hline & $\mathrm{NH}_{4} \mathrm{SCN}$ & $1.81 \times 10^{-4}$ & - & - & [203] \\
\hline & $\mathrm{NH}_{4} \mathrm{SCN}$-Glycerol & $1.51 \times 10^{-3} 7.68 \times 10^{-4}$ & - & - & [203] \\
\hline & $\mathrm{PVA}-\mathrm{NH}_{4} \mathrm{Br}$ & $3.0 \times 10^{-6}$ & - & - & [204] \\
\hline & PVA-LiClO 4 & $1.47 \times 10^{-4}$ & - & Battery & [205] \\
\hline & $\mathrm{NH} 4 \mathrm{CH} 3 \mathrm{COO}-\mathrm{EC}$ & $1.47 \times 10^{-4}$ & $1.83 \mathrm{~mW} \mathrm{~cm}^{-2}$ & Battery & [206] \\
\hline & $\mathrm{NH}_{4} \mathrm{CH}_{3} \mathrm{COO}-\mathrm{EC}$ & $4.38 \times 10^{-7}$ & $1.36 \mathrm{~mW} \mathrm{~cm}^{-2}$ & - & [206] \\
\hline & Chitosan- $\mathrm{NH}_{4} \mathrm{Br}$ & $2.15 \times 10^{-4}$ & - & - & [207] \\
\hline & Chitosan- $\mathrm{NH}_{4} \mathrm{Br}$-glycerol & $9.72 \times 10^{-5} 1.44 \times 10^{-3}$ & - & - & [207] \\
\hline & Starch blend- $\mathrm{NH}_{4} \mathrm{Br}$ & $3.9 \times 10^{-3}$ & - & EDLC & {$[208,209]$} \\
\hline & Starch blend- $\mathrm{NH}_{4} \mathrm{Br}+\mathrm{EC}$ & $4.0 \times 10^{-5}$ & $0.1400 \mathrm{~mA} \mathrm{~h} \mathrm{~g}{ }^{-1}$ & Battery & {$[208,209]$} \\
\hline & $\mathrm{LiCF}_{3} \mathrm{SO}-\mathrm{EC}-\mathrm{DMC}$ & $4.6 \times 10^{-5}$ & $1.5 \mathrm{~V}$ & - & {$[210]$} \\
\hline & $\mathrm{EC}-\mathrm{LiCF} 3 \mathrm{SO}_{3}$ & $10^{-5}$ & - & Battery & {$[211]$} \\
\hline & Acetic acid- $\mathrm{NaClO}_{4}$ & $5.5 \times 10^{-6}$ & $1.114 \mathrm{~V}$ & - & [212] \\
\hline \multirow[t]{4}{*}{ Carboxymethyl Cellulose } & $\mathrm{NH}_{4} \mathrm{Br}$ & $1.12 \times 10^{-4}$ & - & Battery & [213] \\
\hline & $\mathrm{NH}_{4} \mathrm{~F}$ & $2.68 \times 10^{-7}$ & - & - & [214] \\
\hline & Salicylic acid & $9.50 \times 10^{-8}$ & - & - & [215] \\
\hline & DTAB & $7.72 \times 10^{-4}$ & - & - & [216] \\
\hline
\end{tabular}


Table 3 (continued)

\begin{tabular}{|c|c|c|c|c|c|}
\hline Biopolymer & Additive & $\sigma(\mathrm{S} / \mathrm{cm})$ & Unit & Device & References \\
\hline \multirow{12}{*}{ Methylcellulose (MC) } & DTAB-EC & $2.37 \times 10^{-3}$ & - & - & {$[216]$} \\
\hline & $\mathrm{CH}_{3} \mathrm{COONH}_{4}$ & $5.77 \times 10^{-4}$ & - & - & {$[217]$} \\
\hline & Oleic acid & $2.11 \times 10^{-5}$ & & & [218] \\
\hline & - & $3.08 \times 10^{-11}$ & - & - & [219] \\
\hline & $\mathrm{NH}_{4} \mathrm{NO}_{3}$ & $2.10 \times 10^{-6}$ & - & - & [219] \\
\hline & $\mathrm{NH}_{4} \mathrm{~F}$ & $6.40 \times 10^{-7}$ & - & - & [220] \\
\hline & Glycolic acid & $7.16 \times 10^{-10}$ & - & - & [221] \\
\hline & $\mathrm{MC}-\mathrm{NH}_{4} \mathrm{NO}_{3}$ & $1.17 \times 10^{-4}$ & - & - & {$[222]$} \\
\hline & MC-NH4NO3-PC & $4.91 \times 10^{-3}$ & - & - & [222] \\
\hline & $\mathrm{MC}-\mathrm{NH}_{4} \mathrm{NO}_{3}-\mathrm{EC}$ & $1.74 \times 10^{-2}$ & - & - & [222] \\
\hline & PVDF-MC/PVDF-LiFePO 4 & $1.5 \times 10^{-3}$ & $34 \mathrm{~mA} \mathrm{~g}^{-1}$ & Battery & [223] \\
\hline & $\mathrm{NH}_{4} \mathrm{NO}_{3}-\mathrm{PEG}$ & $1.14 \times 10^{-4}$ & $31.52 \mathrm{~mA} \mathrm{~cm}^{-2}$ & Fuel cell & [224] \\
\hline
\end{tabular}

Table 4

Morphology, treatment conditions and matrix of some of the cellulosic biopolymer materials used as electrolytes in Li-ion batteries [245].

\begin{tabular}{llll}
\hline $\begin{array}{l}\text { Cellulose } \\
\text { form }\end{array}$ & $\begin{array}{l}\text { Treatment/modification } \\
\text { before introduction into } \\
\text { the matrix }\end{array}$ & Polymeric matrix & Ref. \\
\hline $\begin{array}{l}\text { Cellulose } \\
\text { Sheet }\end{array}$ & None a reinforcement of polymeric matrices \\
& Photocured acrylic & {$[246,247]$} \\
mibers & Grafting with acrylic acid & PVA & {$[248]$} \\
NCC & None & $\begin{array}{l}\text { PEO or crosslinked PEO } \\
\text { Ethyleneoxide-epi- }\end{array}$ & {$[249-251]$} \\
NCC & None & $\begin{array}{l}{[252]} \\
\text { chlorohydrin }\end{array}$ & \\
& & $\begin{array}{l}\text { Copolymers } \\
\text { PEO }\end{array}$ & {$[253]$} \\
MFC & None & $\begin{array}{l}\text { Photocured acrylic } \\
\text { matrices }\end{array}$ & {$[254]$} \\
MFC & None & & \\
& & & \\
\hline
\end{tabular}

Table 5

Some of the cellulosic biopolymer materials used as electrolytes in Li-ion batteries [246].

\begin{tabular}{|c|c|c|}
\hline Cellulose Derivative & Treatment/modification & Ref. \\
\hline \multicolumn{3}{|c|}{ Cellulose derivatives used as SPEs or GPEs } \\
\hline Hydroxypropylcellulose & Grafting with PEO & [255] \\
\hline Cellulose triacetate & Plasticization with ionic liquids & [256] \\
\hline Ethylcellulose & Plasticization with glycerol & [257] \\
\hline Ethylcellulose & Grafting with methylmethacrylate & [258] \\
\hline Cellulose acetate & $\begin{array}{l}\text { Plasticization with ionic liquid or eutectic } \\
\text { solvents }\end{array}$ & [259] \\
\hline Cellulose phthalate & None & [260] \\
\hline Cyanoethylated cellulose & None & [261] \\
\hline Cyanoethylated cellulose & Blended with PVDF & [262] \\
\hline Cellulose esters & Esterification with PEO monocarboxylic acid & [263] \\
\hline Hydroxyethylcellulose & Grafted with oligoetherisocyanate & [264] \\
\hline
\end{tabular}

system containing lithium triflate salt. The room temperature conductivity of $\mathrm{LiCF}_{3} \mathrm{SO}_{3}$ electrolyte was higher than that of the $\mathrm{LiCH}_{3} \mathrm{COO}$ electrolyte. The difference in conductivity is associated with the nature of the lithium salt and it is supposed that $\mathrm{LiCF}_{3} \mathrm{SO}_{3}$ salt dissociated more $\mathrm{LiCH}_{3} \mathrm{COO}$ anion. Triflate anion is larger than acetate anion and therefore lithium triflate salt will have lower lattice energy than lithium acetate salt.

Alias et al. [268] reported the porous chitosan- $\mathrm{SiO}_{2}$ membranes prepared by ultrasonic mixing solution-cast and porogen removal method at different $\mathrm{SiO}_{2}$ weight ratios. They soaked these membranes in $\mathrm{NH}_{4} \mathrm{CH}_{3} \mathrm{COO}$ electrolyte solution for two days and obtained a conductivity value of $3.6 \times 10^{-3} \mathrm{~S} / \mathrm{cm}$. The proton battery displayed an open circuit potential of $1.5 \mathrm{~V}$ for 7 days, maximum power density $\left(6.7 \mathrm{~mW} \mathrm{~cm}^{-2}\right)$ and small current resistance $(0.03 \Omega)$. The specific discharge capacities obtained from discharge profile of $39.7 \mathrm{~mA} \mathrm{~h}^{-1}(0.5 \mathrm{~mA})$ and $43.8 \mathrm{~mA} \mathrm{~h}{ }^{-1}(1.0 \mathrm{~mA})$

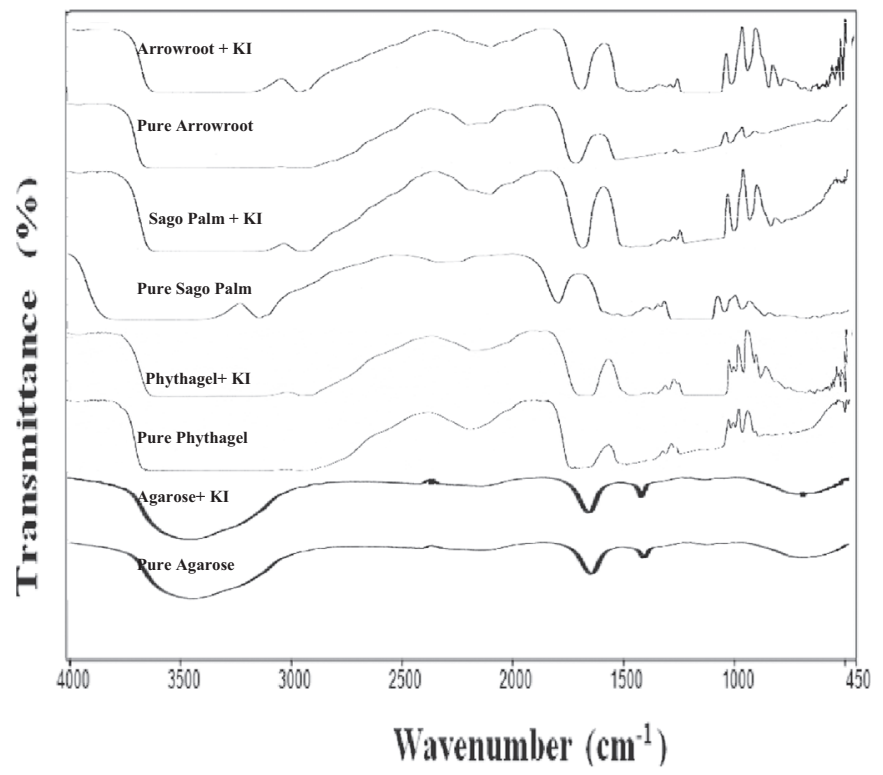

Fig. 4. Infrared spectroscopy of pure biopolymers and biopolymers-KI samples.

increased as the discharge currents were increased. These results indicated that porous chitosan- $\mathrm{SiO}_{2}$ membrane is a suitable membrane for the proton batteries.

Solid polymer electrolytes consisting of chitosan, lithiumbis (trifluoromethylsulfonyl) imide (LiTFSI) as a salt and succinonitrile as a plastic crystal are reported by Taib and Idris [269]. The highest room temperature ionic conductivity observed for the sample Chitosan-LiTFSI containing $50 \mathrm{wt} \%$ succinonitrile exhibited a conductivity of $4 \times 10^{-4} \mathrm{~S} / \mathrm{cm}$, a high lithium ion transference number (0.598) and wide electrochemical window $(4.7 \mathrm{~V})$. This system with $\mathrm{LiFePO}_{4}$ as a cathode, displays a stable discharge capacity of $160 \mathrm{~mA} \mathrm{~h}^{-1}$ for up to 50 cycles at a current density of $17 \mathrm{~mA} \mathrm{~g}^{-1}$. The results demonstrate that this system is potential electrolyte material for lithium rechargeable batteries.

The biopolymer electrolyte based agar complexed with magnesium triflate $\left(\mathrm{Mg}\left(\mathrm{CF}_{3} \mathrm{SO}_{3}\right)_{2}\right)$ has been investigated by Alves et al. [270]. The sample that exhibited the highest conductivity is Agar $_{32.30 \%} \mathrm{Mg}\left(\mathrm{CF}_{3} \mathrm{SO}_{3}\right)_{2}$, and the maximum conductivity values are $1.0 \times 10^{-6}$ and $3.8 \times 10^{-5} \mathrm{~S} \mathrm{~cm}^{-1}$ at $30^{\circ} \mathrm{C}$ and $70{ }^{\circ} \mathrm{C}$, respectively. Agar doped with different ionic liquids has been reported [271,272]. The best conductivity value of $2.35 \times 10^{-5} \mathrm{~S} \mathrm{~cm}^{-1}$ was observed for the agar based on 1-ethyl-3-methylimidazolium acetate composition at ambient temperature. At $100{ }^{\circ} \mathrm{C}$, this electrolyte exhibits a conductivity of about $1.58 \times 10^{-3} \mathrm{~S} \mathrm{~cm}^{-1}$. The highest ionic conductivity value of agar-NiO system is $5.19 \times 10^{-5} \mathrm{~S} / \mathrm{cm}$ at room temperature for the sample with $0.25 \mathrm{~g}$ of $\mathrm{NiO}$. It was also stated 
Table 6

Infrared spectra data of pure biopolymer and KI doped bio-polymer electrolyte system.

\begin{tabular}{|c|c|c|c|c|c|c|c|c|c|c|}
\hline \multicolumn{8}{|c|}{ Wavelength in $\mathbf{c m}^{-1}$} & \multirow[t]{2}{*}{ Freq. ranges } & \multirow[t]{2}{*}{ Groups (bonds) } & \multirow[t]{2}{*}{ Functional groups } \\
\hline $\begin{array}{l}\text { Pure } \\
\text { Arrowroot }\end{array}$ & $\begin{array}{l}\text { Arrow } \\
\text { root }+\mathrm{KI}\end{array}$ & Pure Sago Palm & Sago Palm +KI & $\begin{array}{l}\text { Pure } \\
\text { Agarose }\end{array}$ & Agarose $+\mathrm{KI}$ & Pure Phythagel & Phythagel+KI & & & \\
\hline 3584 & 3372 & 3313 & 3252 & 3445.86 & 3434.15 & 3358 & 3626 & $\begin{array}{l}3500-3200 \\
(\mathrm{~s}, \mathrm{~b}) \\
3640- \\
3610(\mathrm{~s}, \mathrm{sh})\end{array}$ & $\begin{array}{l}\text { O-H stretch, free hydroxyl, } \\
\text { H-bonded }\end{array}$ & alcohols, phenols \\
\hline- & 2929 & 2929 & 2931 & - & - & 2926 & 2921 & $\begin{array}{l}3000-2850 \\
(\mathrm{~m})\end{array}$ & C-H (stretch) & Alkane \\
\hline 2149 & & 2149 & & 2124.66 & 2105.69 & 2126 & 2142 & $\begin{array}{l}2260-2100 \\
(\mathrm{w})\end{array}$ & -CC- stretch & Alkynes \\
\hline 1645 & - & 1642 & - & - & - & - & $1667,1663,1660,1651$ & $\begin{array}{l}1680-1640 \\
(\mathrm{~m})\end{array}$ & $-\mathrm{C}=\mathrm{C}-$ stretch & Alkenes \\
\hline- & 1626 & - & 1633 & 1636.32 & 1637.57 & 1619 & 1644,1614 & $\begin{array}{l}1650-1580 \\
(\mathrm{~m})\end{array}$ & $\mathrm{N}-\mathrm{H}$ bend & $1^{\circ}$ amines \\
\hline \multirow[t]{2}{*}{1462} & 1408 & 1412 & 1454,1416 & 1400.34 & 1400.22 & 1409 & $1445,1427,1416$ & $\begin{array}{l}1500-1400 \\
(\mathrm{~m})\end{array}$ & C-C stretch (in-ring) & Aromatics \\
\hline & - & 1364 & 1372 & - & - & - & - & $\begin{array}{l}1370-1350 \\
(\mathrm{~m})\end{array}$ & $\mathrm{C}-\mathrm{H}$ rock & alkanes \\
\hline \multirow[t]{2}{*}{1169} & $\begin{array}{l}1234,1203, \\
1075\end{array}$ & $1241,1204,1052,1151$ & $\begin{array}{l}1239,1203 \\
1165,1047\end{array}$ & 1121.00 & 1109.07 & $1337,1297,1235,1194$ & 1237,1196, 1171 & $\begin{array}{l}1300-1150 \\
(\mathrm{~m})\end{array}$ & C-O stretch & $\begin{array}{l}\text { alcohols, carboxylic acids, } \\
\text { esters, ether s alkyl halides }\end{array}$ \\
\hline & & & & & & & & $\begin{array}{l}1300-1150 \\
(\mathrm{~m})\end{array}$ & $\mathrm{C}-\mathrm{H}$ wag $\left(-\mathrm{CH}_{2} \mathrm{X}\right)$ & \\
\hline 936 & 935 & 932 & 935 & - & - & 942,924 & 943,923 & $950-910(\mathrm{~m})$ & $\mathrm{O}-\mathrm{H}$ bend & Carboxylic acid \\
\hline 863,787 & $\begin{array}{l}860,762 \\
709\end{array}$ & $859,762,708$ & $860,762,715$ & 687.28 & - & $890,836,812,749,699$ & $891,836,815,755$ & $900-675(\mathrm{~s})$ & C-H "oop" & Aromatics \\
\hline 482 & 607,588 & - & - & 666.77 & $666.72,545.30$ & $666,644,608,565,546,539$ & $666,462,421,407$ & $690-515(\mathrm{~m})$ & C-I stretch & Alkyl halides \\
\hline
\end{tabular}



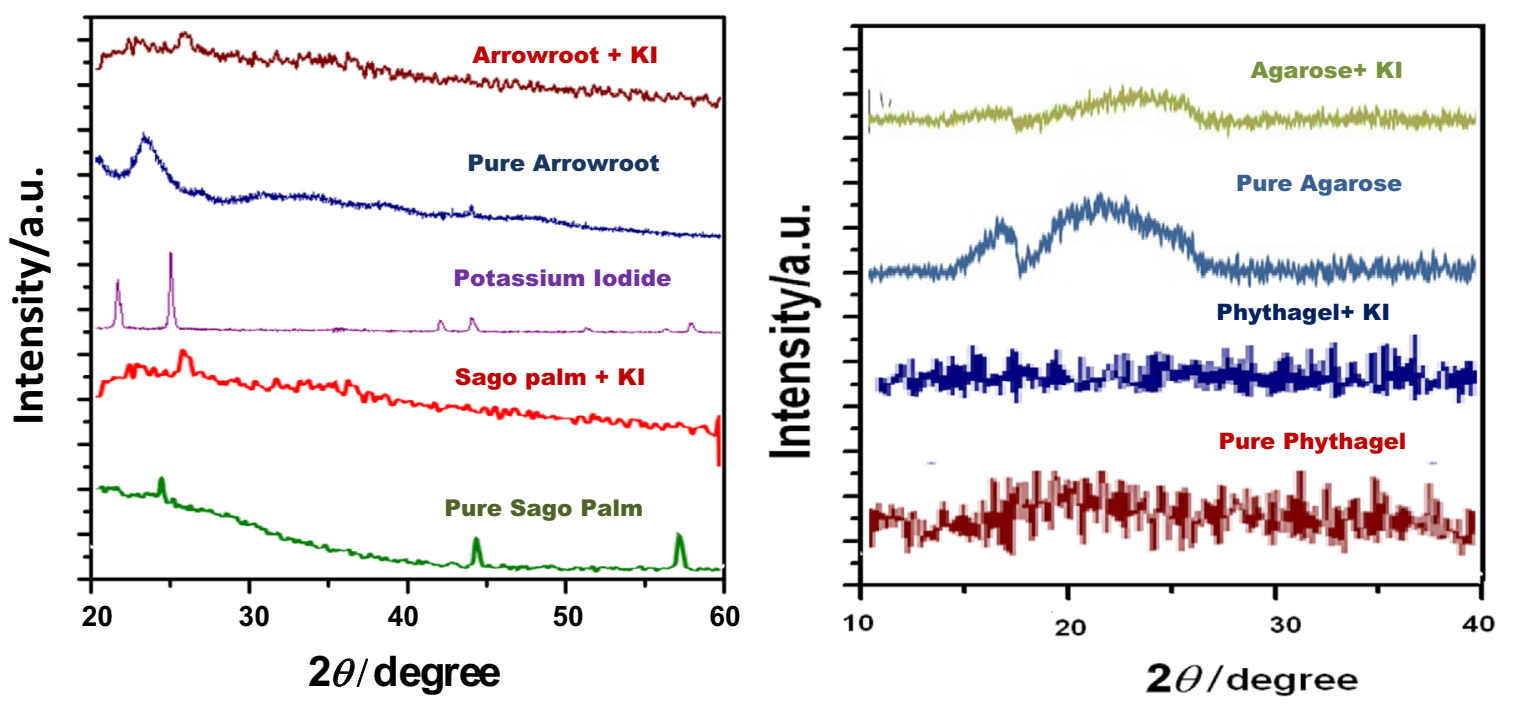

Fig. 5. The XRD pattern of pure biopolymers and KI doped biopolymers systems.

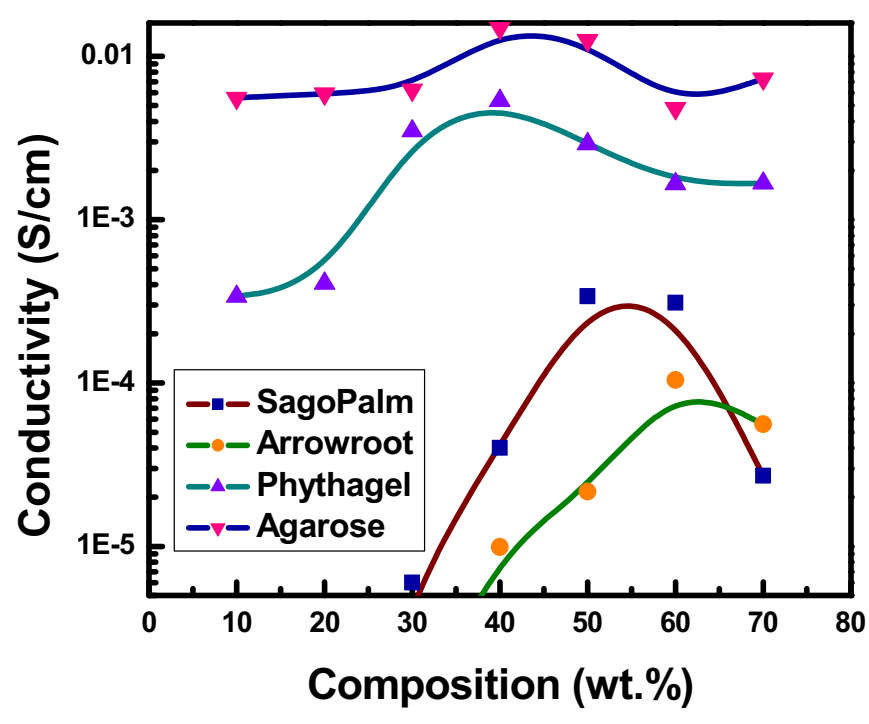

Fig. 6. Ionic conductivity vs composition plot in biopolymers:KI polymer electrolyte system.

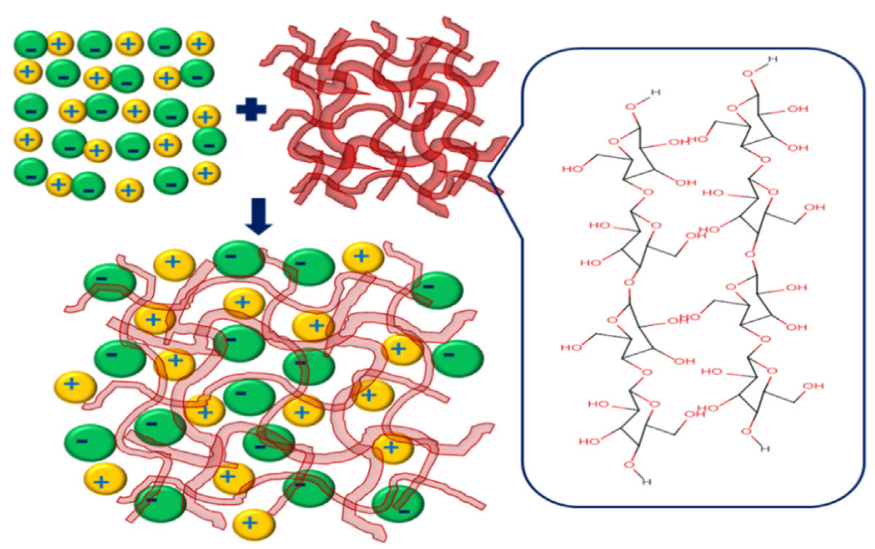

Fig. 7. Schematic diagram showing ion dissocitation in biopolymer salt matrix.

that the increase in temperature up to $80{ }^{\circ} \mathrm{C}$ promoted an increase in the ionic conductivity to $3.32 \times 10^{-4} \mathrm{~S} \mathrm{~cm}^{-1}$ [273].

Pectin-based membranes with different salts such as $\mathrm{LiClO}_{4}$, $\mathrm{KCl}, \mathrm{LiClO}_{4}-\mathrm{Ir}(\mathrm{III})$ and $\mathrm{KCl}-\mathrm{Ir}(\mathrm{III})$ contents are prepared and studied

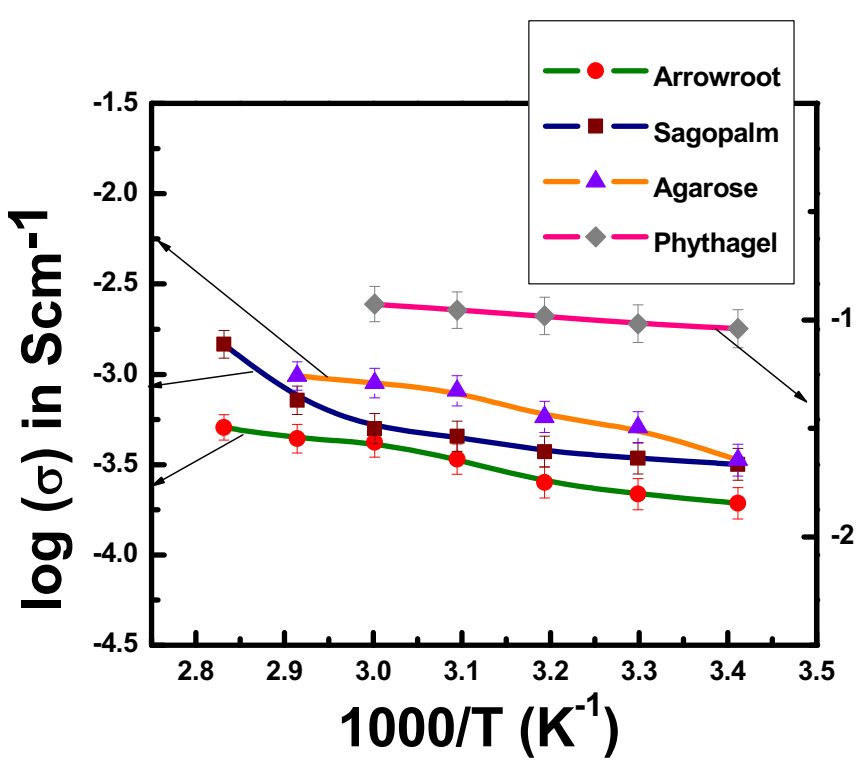

Fig. 8. Variation of conductivity with temperature plot in biopolymers: KI systems.

by Leones et al. [274]. The most conductive sample of Pectin and $\mathrm{KCl}$ exhibits the ionic conductivity of $1.45 \times 10^{-3} \mathrm{~S} \mathrm{~cm}^{-1}$ and $6.31 \times 10^{-3} \mathrm{~S} \mathrm{~cm}^{-1}$ at $25^{\circ} \mathrm{C}$ and $90^{\circ} \mathrm{C}$, respectively. The overall redox stability of $7.0 \mathrm{~V}$ suggests that this material has an acceptable stability window for an application in solid state electrochemical devices. Such a high ionic conductivity, thermal stability and reproducebility affirm the suitability of biopolymers as electrolyte in electrochemical devices.

\section{Recent works by authors}

In our laboratory we have tested a series of biopolymers(like Agarose/ Agars, Sago Starch, Arrowroot Starch, Phythagel)doped with different alkali metal salts and carried out detailed electrical and structural investigations specific for the application area of DSSCs $[101,136,137,166]$. The experimental observations and discussions are described below. 


\subsection{Structural measurements}

\subsubsection{FTIR studies}

Fourier Transform Infrared Spectroscopy (FTIR) spectra of pure biopolymer and biopolymers doped with KI were recorded using Perkin Elmer 883 IR spectrophotometer between 4000 and $450 \mathrm{~cm}^{-1}$ [276-280] (Fig. 4). The different bands assigned to various functional groups are listed in Table 6. Major differences observed in the stretching peaks of the biopolymers with the addition of $\mathrm{KI}$ are at the frequency ranges of $-\mathrm{OH}$ and $-\mathrm{C}-\mathrm{O}$ functional groups. This indicates complex formation between the biopolymer and $\mathrm{KI}[1,2,4,26]$.

\subsubsection{XRD studies}

Fig. 5 shows the X-ray diffraction patterns (XRD) of biopolymerKIelectrolytes obtained by using Rigaku D/max-2500 with a scan rate of $2^{\circ} \mathrm{min}$. It is evident that all salts are well dissolved in biopolymer matrix which is affirmed by the disappearance of the crystallinity ofbiopolymer with the addition of KI. Doping of salt broadens the peak which is clear indication of increase in the amorphous behavior of biopolymer-KI. The decrease in crystallinity (or the increase in amorphicity) by salt doping has the potential of enhancing the overall ionic conductivity of the system.

\subsection{Electrical measurements}

\subsubsection{Electrical conductivity measurements}

The ionic conductivity measurements of the biopolymer-KI based electrolyte films were carried out using a $\mathrm{CH}$ instrument workstation (model CHI604D, USA) over frequency range of $100 \mathrm{~Hz}$ to $1 \mathrm{MHz}$. Free standing biopolymer electrolyte films were sandwiched between two steel electrodes and the electrical conductivity were evaluated using the below formula

$\sigma=\frac{1}{R_{\mathrm{b}}}\left(\frac{l}{A}\right)$

where, $\sigma$ is the ionic conductivity, $R_{\mathrm{b}}$ is the bulk resistance, $l$ is the thickness of sample and $A$ is the area of given sample.

The calculated $\sigma$ values of the biopolymer-xwt\%KI based electrolytes are shown in Fig. 6. It was found that presence of $\mathrm{KI}$ in biopolymer matrix enhances the ionic conductivityup to a certaindoping ratio. The increase in the ionic conductivity with increasing KI concentration is generally correlated with the increase in the number of mobile charge carriers while the reduction observed in this value after reaching a maximacan be attributed to

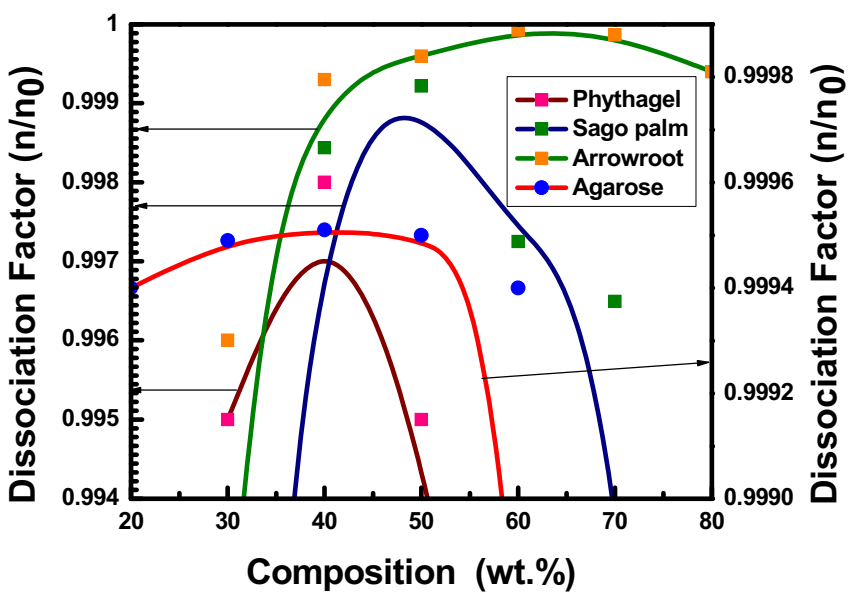

Fig. 9. Change in relative number of charge carriers with increasing amount of $\mathrm{KI}$ in biopolymers:KI polymer electrolyte matrix.

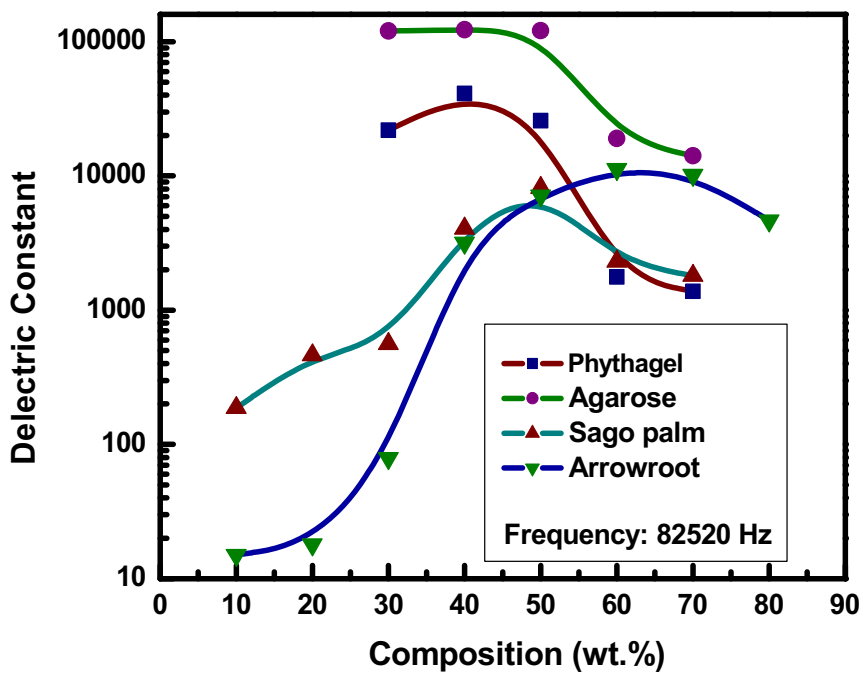

Fig. 10. Dielectric constant vs composition plot of biopolymers:KI polymer elec trolyte system.

the formation of ion multiples [136,163,166]. The effect of salt concentration in biopolymer electrolyte matrix is demonstrated through dissociated ions model in Fig. 7. The impedance measurement data clearly explains the role of charge carriers in the biopolymer electrolyte matrix. It can be seen that both mobile concentration factor and dissociated charge fraction, which are bothrelated with mobile ion concentration data, are following the conductivity trend.Hence, ion pair formation and re-dissociation theory is applicable in biopolymer-salt complex systems. Minimum conductivity is due to the decreased dissociation. Increased ion association, i.e. decreased dissociation or triplet ion formation, both contribute to the decrement in mobility [101,136,163].

The ionic conductivity $(\sigma)$ in case of ion conducting electrolyte system is given as

$\sigma=n \cdot q \cdot \mu$

where $\mathrm{n}$ the is charge carrier density, $\mathrm{q}$ is the charge of the carrier and $\mu$ is the mobility of the carriers. Therefore any increase in either of the parameters $\mathrm{n}$ or $\mathrm{q}$ will certainly affected the value of ionic conductivity.

Here the concentration of free charge carrier's density can be given by:

$n=\left[\frac{\sigma_{\mathrm{DC}}}{\left(\sqrt{\frac{\epsilon^{\prime} \omega}{\epsilon_{\mathrm{s}}}-1}\right) \epsilon_{0} \epsilon_{\mathrm{s}}^{\prime} \omega_{\mathrm{x}}}\right]^{4} \epsilon_{0} \epsilon_{\mathrm{s}} \frac{k T}{e^{2} d^{2}}$

$\sigma_{\mathrm{DC}}$ is the conductivity at high frequency, $\varepsilon_{0}$ is vacuum permittivity, $k$ is Boltzmann constant, $\varepsilon_{s}^{\prime}$ and $\varepsilon^{\prime}{ }_{\omega}$ are the real permittivity at high frequency and at the frequency of $\omega$, respectively and $d$ is the thickness of the sample. Here, $\varepsilon_{s}^{\prime}$ is the real part of the dielectric permittivity in the high frequency region and $\omega_{\mathrm{x}}$ is the angular frequency for which $\varepsilon^{\prime}\left(\omega_{\mathrm{x}}\right)=10 \varepsilon^{\prime}$. Adding KI in biopolymermatrix provides additional mobile charge species,i.e. in present case $\mathrm{K}^{+}$cation and $\mathrm{I}^{-}$anion, and hence ionic conductivity enhances. Variation in number of charge carriers and mobility with KI concentrationcan be easily understood using Eq. (2). In most of the systems we have observed that the number of charge carriers remains almost same. Beyond certain fixed wt\% of dispersoid, the increase in mobility dominates by the decrease in the carrier concentration. This is due to the fact that as the salt concentration increases the amorphicity of the biopolymer matrix increases, thereby allowing more paths to the ions to migrate. As a result the conductivity increases with the addition of the salt 
Table 7

The recorded photovoltaic parameters of DSSC observed in biopolymers-salt matrix.

\begin{tabular}{|c|c|c|c|c|c|c|c|c|c|c|c|}
\hline \multicolumn{2}{|c|}{ Composition for Agarose/Agar based Biopolymer } & \multirow{2}{*}{$\begin{array}{l}\text { Dye } \\
\text { N719 }\end{array}$} & \multirow{2}{*}{$\begin{array}{l}\begin{array}{l}\text { Working } \\
\text { Electrode }\end{array} \\
\text { FTO-TiO }_{2}\end{array}$} & \multirow{2}{*}{$\begin{array}{c}\sigma\left(\mathrm{Scm}^{-1}\right) \\
9.02 \times 10^{-3}\end{array}$} & \multirow{2}{*}{$\begin{array}{c}\text { Jsc } \mathbf{~ m A c m ~}^{-2} \\
3.27\end{array}$} & \multirow{2}{*}{$\begin{array}{l}\text { Voc }(\boldsymbol{V}) \\
0.670\end{array}$} & \multirow{2}{*}{$\begin{array}{l}\text { FF (\%) } \\
0.24\end{array}$} & \multirow{2}{*}{$\begin{array}{l}\begin{array}{l}\text { Area } \\
\left(\mathbf{c m}^{2}\right)\end{array} \\
0.6\end{array}$} & \multirow{2}{*}{$\begin{array}{l}n(\%) \\
0.54\end{array}$} & \multirow{2}{*}{$\begin{array}{l}\begin{array}{l}\text { Intensity } \\
\mathbf{m W ~}^{-2}\end{array} \\
100\end{array}$} & Ref. \\
\hline $\mathrm{KI}-\mathrm{I}_{2}$ & & & & & & & & & & & [101] \\
\hline $\mathrm{NH}_{4} \mathrm{I}-\mathrm{I}_{2}$-Glycerol & & N719 & ITO-ZnO & $4.89 \times 10^{-3}$ & 0.007 & 0.29 & - & 1 & - & 100 & [103] \\
\hline MPII-PC/DMSO-GuSCN-NMBI-I ${ }_{2}$ & & N719 & FTO-TiO 2 & - & 11.73 & 0.70 & 0.64 & 0.283 & 5.25 & 100 & [105] \\
\hline AEII -PC/DMSO-GuSCN-NMBI-I ${ }_{2}$ & & N719 & $\mathrm{FTO}^{-\mathrm{TiO}_{2}}$ & - & 11.71 & 0.72 & 0.65 & 0.283 & 5.45 & 100 & [105] \\
\hline APII -PC/DMSO-GuSCN-NMBI-I ${ }_{2}$ & & N719 & FTO-TiO 2 & - & 11.53 & 0.70 & 0.62 & 0.283 & 4.97 & 100 & [105] \\
\hline DAII-PC/DMSO-GuSCN-NMBI-I ${ }_{2}$ & & N719 & FTO-TiO ${ }_{2}$ & - & 11.84 & 0.70 & 0.60 & 0.283 & 4.96 & 100 & [105] \\
\hline DMSO/PC- MPII- GuSCN-NMBI-I ${ }_{2}$ & & N719 & $\mathrm{ITO} / \mathrm{TiO}_{2}$ & $14.2 \times 10^{-3}$ & 4.65 & 0.73 & 0.58 & 0.25 & 1.97 & 100 & [107] \\
\hline DMSO/4EG-MPII- GuSCN-NMBI-I ${ }_{2}$ & & N719 & $\mathrm{ITO} / \mathrm{TiO}_{2}$ & $4.4 \times 10^{-3}$ & 3.69 & 0.65 & 0.57 & 0.25 & 1.38 & 100 & [107] \\
\hline DMSO/3EG-MPII- GuSCN-NMBI-I ${ }_{2}$ & & N719 & $\mathrm{ITO} / \mathrm{TiO}_{2}$ & $4.6 \times 10^{-3}$ & 4.01 & 0.61 & 0.57 & 0.25 & 1.39 & 100 & [107] \\
\hline DMSO/PG- MPII- GuSCN-NMBI-I & & N719 & $\mathrm{ITO} / \mathrm{TiO}_{2}$ & $6.2 \times 10^{-3}$ & 3.21 & 0.58 & 0.57 & 0.25 & 1.06 & 100 & [107] \\
\hline DMSO- MPII- GuSCN-NMBI-I ${ }_{2}$ & & N719 & $\mathrm{ITO} / \mathrm{TiO}_{2}$ & $5.0 \times 10^{-3}$ & 3.69 & 0.58 & 0.54 & 0.25 & 1.15 & 100 & [107] \\
\hline $\mathrm{TiO}_{2}-\mathrm{NMP}-\mathrm{LiI} / \mathrm{I}_{2}$ & & N719 & FTO-TiO 2 & $2.66 \times 10^{-3}$ & 5.28 & 0.605 & 0.55 & 0.25 & 1.71 & 100 & [110] \\
\hline $\mathrm{Co}_{3} \mathrm{O}_{4}-\mathrm{NMP}-\mathrm{LiI} / \mathrm{I}_{2}$ & & N719 & $\mathrm{FTO}^{-\mathrm{TiO}_{2}}$ & $4.37 \times 10^{-3}$ & 7.24 & 0.635 & 0.46 & 0.25 & 2.11 & 100 & [110] \\
\hline NiO-NMP- LiI/I 2 & & N719 & $\mathrm{FTO}^{-\mathrm{TiO}_{2}}$ & $3.33 \times 10^{-3}$ & 6.20 & 0.625 & 0.52 & 0.25 & 2.02 & 100 & [110] \\
\hline $\mathrm{LiI} / \mathrm{I}_{2}-\mathrm{NMP}$ & & - & $\mathrm{TiO}_{2}$ & $3.94 \times 10^{-4}$ & 8.24 & 0.597 & 0.62 & 0.25 & 4.14 & 73 & {$[111,112]$} \\
\hline $\mathrm{LiI} / \mathrm{I}_{2}-\mathrm{NMP}$-nanoparticle $\mathrm{TiO}_{2}$ & & - & $\mathrm{TiO} 2$ & $4.4 \times 10^{-4}$ & 10.96 & 0.545 & 0.57 & 0.25 & 4.74 & 73 & [112] \\
\hline AN/MOZ- TBP- $\mathrm{I}_{2} / \mathrm{LiI}-\mathrm{Pr}_{4} \mathrm{NI}+\mathrm{I}^{3-}$ & & N3 & FTO/ITO $/ \mathrm{TiO}_{2}$ & $4.36 \times 10^{-3}$ & 14.00 & 0.76 & 0.66 & 0.20 & 7.06 & 100 & [117] \\
\hline 1-alkyl-3-methylimidazoliumIodides- $\mathrm{LiI} / \mathrm{I}_{2}-\mathrm{NI}$ & MP & N719 & $\mathrm{FTO} / \mathrm{TiO}_{2}$ & - & 6.77 & 0.650 & 0.66 & 0.25 & 2.93 & 100 & [113] \\
\hline $\mathrm{LiI} / \mathrm{I}_{2}-\mathrm{NMP}-\mathrm{Fe}_{3} \mathrm{O}_{4}-$ polysorbate 80 & & N719 & $\mathrm{FTO} / \mathrm{TiO}_{2}$ & $2.98 \times 10^{-3}$ & 5.00 & 0.7 & 0.53 & - & 1.83 & 100 & [108] \\
\hline $\mathrm{LiI} / \mathrm{I}_{2}-\mathrm{NMP}-\mathrm{Fe}_{3} \mathrm{O}_{4}-\mathrm{PEG} 200$ & & N719 & $\mathrm{FTO} / \mathrm{TiO}_{2}$ & - & 3.70 & 0.67 & 0.61 & - & 1.50 & 100 & [108] \\
\hline $\mathrm{LiI} / \mathrm{I}_{2}-\mathrm{NMP}-\mathrm{Fe}_{3} \mathrm{O}_{4}-\mathrm{PVP}$ & & N719 & $\mathrm{FTO} / \mathrm{TiO}_{2}$ & - & 3.00 & 0.67 & 0.59 & - & 1.19 & 100 & [108] \\
\hline $\mathrm{LiI} / \mathrm{I}_{2}-\mathrm{NMP}-\mathrm{Fe}_{3} \mathrm{O}_{4}-\mathrm{SDS}$ & & N719 & $\mathrm{FTO} / \mathrm{TiO}_{2}$ & - & 3.18 & 0.66 & 0.62 & - & 1.29 & 100 & [108] \\
\hline Composition & Dye & & $\begin{array}{l}\text { Working } \\
\text { electrode }\end{array}$ & $\sigma\left(S \mathrm{~cm}^{-1}\right)$ & $J s c ~ m A ~ ~ c m^{-2}$ & $\operatorname{Voc}(V)$ & FF (\%) & $\begin{array}{l}\text { Area } \\
\left(\mathrm{cm}^{2}\right. \\
)\end{array}$ & $\eta(\%) \quad I$ & Intensity $\mathrm{mW} \mathrm{cm}^{-2}$ & 2 Ref. \\
\hline Carrageenan- AN/MOZ- TBP-I $2 / \mathrm{LiI}_{-} \mathrm{Pr}_{4} \mathrm{NI}+\mathrm{I}^{3-}$ & N3 & & $\mathrm{FTO} / \mathrm{ITO} / \mathrm{TiO}_{2}$ & $2.92 \times 10^{-3}$ & 14.67 & 0.73 & 0.67 & 0.20 & 6.87 & 100 & [117] \\
\hline Carrageenan-AN/MOZ-TBP-I $\mathrm{I}_{2} / \mathrm{LiI}-\mathrm{I}^{-} / \mathrm{I}^{3-}$ & N3 & & FTO/ITO $/ \mathrm{TiO}_{2}$ & - & 14.67 & 0.73 & 0.67 & 0.20 & 6.87 & 100 & [117] \\
\hline Carrageenan-AN/MOZ-(Pr) ${ }_{4} \mathrm{NI}_{-} \mathrm{I}_{2}-\mathrm{LiI}-\mathrm{TBP}$ & N3 & & $\mathrm{PEN} / \mathrm{ITO} / \mathrm{TiO}_{2}$ & - & 2.68 & 0.80 & 0.72 & 0.25 & 1.54 & 100 & [116] \\
\hline Carrageenan- AN/MOZ-(Pr) ${ }_{4} \mathrm{NI}^{-} \mathrm{I}_{2}-\mathrm{LiI}-\mathrm{TBP}$ & N3 & & FTO- $\mathrm{TiO}_{2}$ & - & 8.67 & 0.75 & 0.65 & 0.25 & 4.23 & 100 & [116] \\
\hline Gellan gum $+\mathrm{KI}$ & N719 & & $\mathrm{FTO}^{-\mathrm{TiO}_{2}}$ & 0.00534 & 0.0666 & 0.57 & 0.57 & 0.45 & 0.56 & 100 & - \\
\hline Sago Starch + KI & N719 & & $\mathrm{FTO}^{-\mathrm{TiO}_{2}}$ & $3.4 \times 10^{-4}$ & 0.0291 & 0.582 & 0.60 & 0.45 & $0.578 \quad 1$ & 100 & [136] \\
\hline $\begin{array}{l}\text { Amylopectin-DMSO-I } 2 \text {-LiI-DMHIm-(4- } \\
\text { tertbutylpyridine) }\end{array}$ & N719 & & $\mathrm{FTO}^{-\mathrm{TiO}_{2}}$ & - & 6.83 & 0.74 & 0.66 & 0.16 & $3.34 \quad 1$ & 100 & [148] \\
\hline Arrowroot starch $+\mathrm{KI}$ & N719 & & FTO-TiO ${ }_{2}$ & $1.04 \times 10^{-4}$ & 0.0568 & 0.56 & - & 0.45 & 0.63 & 100 & [165] \\
\hline Rice-LiI:MPII:TiO ${ }_{2}$ & N3 & & $\mathrm{ITO} / \mathrm{TiO}_{2}$ & $3.63 \times 10^{-4}$ & 0.49 & 0.45 & 0.75 & 0.25 & 0.17 & 100 & [159] \\
\hline Chitosan-NaI- $\mathrm{I}_{2}$ & - & & FTO-TiO 2 & - & 1.05 & 0.349 & 0.34 & 0.16 & 0.13 & 100 & [175] \\
\hline Chitosan-NaI-I 2 -EMImSCN & - & & FTO-TiO 2 & $2.60 \times 10^{-4}$ & 2.62 & 0.53 & 0.52 & 0.16 & 0.73 & 100 & [175] \\
\hline Chitosan- $\mathrm{NH}_{4} \mathrm{I}-\mathrm{I}_{2}$ & - & & $\mathrm{ITO}_{\mathrm{TiO}}$ & $3.73 \times 10^{-7}$ & 0.0049 & 0.15 & 0.22 & 0.09 & 0.29 & 56.4 & [178] \\
\hline Chitosan- $\mathrm{NH}_{4} \mathrm{I}-\mathrm{I}_{2}-\mathrm{EC}$ & - & & $\mathrm{ITO}^{-\mathrm{TiO}_{2}}$ & $7.34 \times 10^{-6}$ & 0.0072 & 0.22 & 0.18 & 0.09 & 0.51 & 56.4 & [178] \\
\hline Chitosan- $\mathrm{NH}_{4} \mathrm{I}-\mathrm{I}_{2}-\mathrm{BMII}$ & - & & ITO- $\mathrm{TiO}_{2}$ & $8.47 \times 10^{-4}$ & 0.0192 & 0.26 & 0.14 & 0.09 & 1.24 & 56.4 & [178] \\
\hline Chitosan-NH4 $\mathrm{I}-\mathrm{BMII}$ & $\begin{array}{l}\text { Black } \\
\text { antho }\end{array}$ & $\begin{array}{l}\text { rice } \\
\text { cyanin }\end{array}$ & $\mathrm{ITO} / \mathrm{TiO}_{2}$ & $3.02 \times 10^{-4}$ & 0.9 & 3.65 & 0.45 & 0.16 & 0.15 & 100 & {$[179]$} \\
\hline Chitosan-PEO-NH $\mathrm{N}_{4} \mathrm{I}-\mathrm{I}_{2}-\mathrm{BMII}$ & $\begin{array}{l}\text { Black } \\
\text { antho }\end{array}$ & $\begin{array}{l}\text { rice } \\
\text { cyanin }\end{array}$ & $\mathrm{ITO}_{\mathrm{TiO}}$ & $5.52 \times 10^{-4}$ & 1.213 & 4.00 & 0.47 & 0.16 & 0.23 & 100 & [179] \\
\hline Tartaric-Phthaloyl Chitosan- $\mathrm{NH}_{4} \mathrm{I}$-BMII & $\begin{array}{l}\text { Red ca } \\
\text { antho }\end{array}$ & $\begin{array}{l}\text { abbage } \\
\text { cyanin }\end{array}$ & $\mathrm{ITO}^{-\mathrm{TiO}_{2}}$ & $5.86 \times 10-4$ & 3.472 & 3.65 & 0.34 & 0.16 & 0.43 & 100 & [179] \\
\hline Tartaric-Phthaloyl Chitosan-PEO-NH $4 \mathrm{I}$-BMII. & $\begin{array}{l}\text { Red } \mathrm{c} \\
\text { antho }\end{array}$ & $\begin{array}{l}\text { abbage } \\
\text { cyanin }\end{array}$ & ITO-TiO 2 & $6.24 \times 10^{-4}$ & 3.503 & 3.40 & 0.39 & 0.16 & 0.46 & 100 & [179] \\
\hline Chitosan-PEO-NH${ }_{4} \mathrm{I}-\mathrm{I}_{2}$ & $\begin{array}{l}\text { Lawso } \\
\text { inerm }\end{array}$ & & $\mathrm{ITO} / \mathrm{TiO}_{2}$ & $1.18 \times 10^{-5}$ & 0.38 & 336 & 0.57 & 0.05 & 0.7 & 100 & [181] \\
\hline Chitosan-PEO-NH${ }_{4} \mathrm{I}-\mathrm{I}_{2}$ & Suma & c/Rhus & ITO/TiO ${ }_{2}$ & $1.18 \times 10^{-5}$ & 0.93 & 394 & 0.41 & 0.05 & 1.5 & 100 & [181] \\
\hline Chitosan-PEO-NH${ }_{4} \mathrm{I}-\mathrm{I}_{2}$ & $\begin{array}{l}\text { Curcu } \\
\text { longa }\end{array}$ & & $\mathrm{ITO} / \mathrm{TiO}_{2}$ & $1.18 \times 10^{-5}$ & 0.20 & 280 & 0.65 & 0.05 & 0.36 & 100 & [181] \\
\hline
\end{tabular}

concentration and attains a maximum. This means that the conductivity is not affected by the value of $n$, and depends on the movement and distribution of charge carriers. At high salt concentrations, ions move in the sample within very short distances and mobility does not affect the conductivity.

\subsubsection{Temperature dependentconductivity measurement}

Temperature dependent ionic conductivity of solid biopolymer electrolytesare shown in Fig. 8. It is clear that with increasing temperature, the ionic conductivity values increases and follow Arrhenius type behavior. Linear relations are observed in all biopolymer electrolytes, which mean that there is no phase transition in the biopolymer matrix or no domain formed by the addition of
KI. These experiments are restricted by the $T_{g}$ (glass transition) temperature where bio polymers start phase transition. Variation of conductivity is given with the equation below by considering Arrhenius type behavior

$\sigma=\sigma_{0} \exp \left(\frac{-E_{\mathrm{a}}}{k T}\right)$

where, $\sigma_{0}$ is the pre-exponential factor, $E_{a}$ is the activation energy and $\mathrm{k}$ is the Boltzmann constant. From this relationship, the $\mathrm{E}_{\mathrm{a}}$ of biopolymer electrolyteswith maximum conductivity values are calculated. The values obtained are $0.33,0.40,0.39$ and $0.24 \mathrm{eV}$ for the biopolymer electrolytes Sago Palm, Arrowroot, Agarose and Phythagel systems respectively. 


\subsubsection{Ion dissociation factor}

To further clarify the role of charge carriers in biopolymer electrolyte matrix we have evaluated the room temperature dissociation factor $\left(n / n_{0}\right)$ for all studied biopolymers-salt samples. The change in the relative number of charge carriers $\left(n / n_{0}\right)$ with increasing wt\% KI are shown in Fig. 9. It is observed that at the maximum doping limit, the $n / n_{0}$ values reach amaximum as well and then presentsa decreasing trend; follows the same trend observed inconductivity and dielectric measurements. Therefore, the conductivity, in biopolymers:KI matrix is predominantly governed by the number of charge carriers as suggested by Barker [275] (electrolyte dissociation theory) using the equation

$n=n_{0} \exp \{-U / 2 \epsilon k T\}$

where, $U$ is the dissociation energy of the salt, $k$ is Boltzmann constant, $\varepsilon$ is the dielectric constant of the system, and $T$ is the temperature of the sample.

\subsubsection{Dielectric studies}

The information about different molecular motion and relaxation processes, are well correlated with the dielectric studies. Dielectric measurements are extremely sensitive to smallchanges in material properties (molecular relaxation of the order of only a few nanometer involves dipole changes that can be observed by dielectric study). In order to justify the overall contribution of the number of free charge carriers in the total conductivity, the dielectric constant $(\varepsilon)$ of the biopolymer electrolyte filmsarecalculated. Fig. 10 shows the change in dielectric constant with increasing amount of $\mathrm{KI}$ in the biopolymer electrolyte at one typical frequency i.e. at $82520 \mathrm{~Hz}$. It is clear that conductivity data are well matched with the dielectric data. The addition of KI in the biopolymers causes changes in the dielectric constant of the matrix, which effects the number of free charge carriers and thereby the conductivity.

\subsubsection{Ionic transference number measurement using DC polarization method}

Using this simple method, we have evaluated the percentage of ionic or electronic nature in biopolymer:KI electrolyte films. Fixed DC potential of $0.25 \mathrm{~V}$ is applied for $\sim 6 \mathrm{~h}$ to the steel plate/biopolymer electrolyte/steel plate system. The DC current is monitored with respect to time using Keithley 2400 source meter. After applying a DC potential,due to the ionic movement (ions start moving towards the other donor site)current is increased initially and after attaining the peak current it is saturated and decreasing trend is appeared (Fig. not shown here). By monitoring initial current and final current and using Eq. (6), the ionic transference numbers of biopolymer electrolytes are calculated as 0.94, 0.93, 0.82, 0.92 for Sago Palm, Arrowroot, Agarose and Phythagel systems respectively, which confirms the ionic nature of the biopolymers electrolyte system.

$t_{\text {ion }}=\frac{I_{\text {initial }}-I_{\text {final }}}{I_{\text {initial }}}$

\subsection{Dye sensitized solar cell performance (I-V curve)}

The photovoltaic performance ( $I-V$ curve) of the DSSCs aremeasured with Keithley 2400 source meter under 1 sun light condition (Fig. not shown). For developing redox couple in biopolymer-KI electrolyte system, addition of iodine in the polymer matrix is needed.DSSCs arefabricated by using the highest ionic conductivity composition of the electrolytes. The different photovoltaic parameters such as $\mathrm{J}_{\mathrm{sc}}\left(\mathrm{A} \mathrm{cm}^{-2}\right), \mathrm{V}_{\mathrm{oc}}(\mathrm{V}), \mathrm{FF}(\%)$, Area $\left(\mathrm{cm}^{2}\right)$ and light intensity in biopolymers: salt matrix developed in our laboratory $[101,136,137,166]$ as well as exist in literature are listed in Table 7 [101-181].

\section{Conclusions}

This review article provides a thorough overview of the structure, occurrence, and properties- chemical, physical, electrical with technical applications of the most biopolymers generated by different sources. We have successfully presented collective data on the additives used by the researchers to enhance the ionic conductivity of biopolymer based electrolytes for device performance particularly on DSSC and battery. It was observed that the biopolymer electrolytes in general followed Arrhenius type of behavior and its ionic conductivity is predominantly governed by the ionic charge carriers. Structural studies revealed that the complexion of biopolymer with dispersoids (salts) decreses the crystallinity of biopolymer matrix and consequently enhances the amorphous region and hence conductivity increases drastically. These biopolymer-salt complexed systems possess high conductivity values $\left(10^{-3}\right.$ to $\left.10^{-4} \mathrm{~S} / \mathrm{cm}\right)$ which further affirm that biopolymer electrolyte could be a novel alternative in developing highly efficient DSSC and battery and help the scientific community to keep the environment clean and ecofriendly.

\section{Acknowledgments}

The authors are thankful to the Scientists/researchers on sabbatical leave, 2221 support program of the Scientific and Technological Research Council of Turkey, TUBITAK, Department of Science \& Technology project (DST/TSG/PT/2012/51-C) government of India and National Research Foundation under the Ministry of Science, ICT \& Future Planning, Korea (2011-0031570).

\section{References}

[1] MacCallum JR, Vincent CA. Polymer Electrolyte Reviews. Elsevier: London; 1987 and 1989. 1 and 2.

[2] Gray FM, editor. Solid Polymer Electrolytes: Fundamentals and Technological Applications. New York: VCH Publishers; 1991.

[3] Kato Y, Hori S, Saito T, Suzuki K, Hirayama M, Mitsui A, Yonemura M, Iba H, Kanno R. High-power all-solid-state batteries using sulfide superionic conductors. Nat Energy 2016;1:16030.

[4] Xue Z, He D, Xie X. Poly(ethylene oxide)-based electrolytes for lithium-ion batteries. J Mater. Chem. A 2015;3:19218.

[5] Steinbuchel A. Biopolymers, general aspects and special applications.Weinheim: Wiley-VCH; 2003. p. 10.

[6] Chandra R, Rustgi R. Biodegradable polymers. Prog Polym Sci 1998;23 (7):1273-335.

[7] Özdemir C, Güner A. Solubility profiles of poly (ethylene glycol)/solvent systems, I: Qualitative comparison of solubility parameter approaches. Eur Polym J 2007;43(7):3068-93.

[8] Amelia RPD, Tomic JC, Nirode WF. The determination of the solubility parameter $(\delta)$ and the Mark-Houwink constants ( $\& \alpha \alpha)$ of food grade Polyvinyl Acetate (PVAc). J Polym Biopolym Phys Chem 2014;2(4):6772.

[9] Lenz RW. Biodegradable polymer. Adv Polym Sci 1993;107:1-40.

[10] Stephen AM, Phillips GO, Williams PA. Food Polysaccharides and their Applications.Second Edition. Taylor \& Francis Group LLC; 2006.

[11] Finkenstadt VL. Natural polysaccharides as electroactive polymers. Appl Microbiol Biotechnol 2005;67:735-45.

[12] Smalley RE. Future global energy prosperity: the terawatt challenge. MRS Bull 2005;30:412-7.

[13] Dumitriu S. Polysaccharides: structural diversity and functional versatility ed. New York City: Marcel Dekker, Inc.; 1998.

[14] Rees DA. Polysaccharide shapes, outline studies in biology.Netherlands: Springer; 1977.

[15] Habibi Y, Lucia LA. Polysaccharide building blocks: a sustainable approach to the development of renewable biomaterials.United States: John Wiley and Sons Ltd; 2012. p. 430.

[16] Finkenstadt VL, Willett JL. Preparation and characterization of electroactive biopolymers. Macromol. Symp 2005;227(1):367-72. 
[17] Finkenstadt VL, Willett JL. Electroactive materials composed of starch. J Polym Environ 2004;12(2):43-6.

[18] Nijenhuis K. Thermoreversible networks - viscoelastic properties and structure of gels. Adv Polym Sci 1997;130:194-202.

[19] CampoVI, Kawano DF, Braz da Silva Jr D, Carvalho I. Carrageenan: biologica properties, chemical modifications and structural analysis - a review. Carbohydr Polym 2009;77:167-80.

[20] Augst AD, Kong HJ, Mooney DJ. Alginate hydrogels as biomaterials. Macromol Biosci 2006:6:623-33.

[21] Kalia S, Kaith BS, Kaur I. Cellulose fibers: bio- and nano-polymer composites. green chemistry and technology.Berlin Heidelberg: Springer; 2011.

[22] Le CD, Bras J, Dufresne A. Starch nanoparticles: a review. Biomacromolecules 2010;11:1139-53.

[23] Ali BH, Ziada A, Blunden G. Biological effects of gum arabic: a review of some recent research. Food Chem Toxicol 2009;47:1-8.

[24] Rinaudo M. Chitin and chitosan: properties and applications. Prog Polym Sci 2006;31:603-32.

[25] Ohno H, editor. Electrochemical Aspects of Ionic Liquids. New Jersey: VCHinterscience; 2005.

[26] Sequeira C, Santos D. Polymer electrolytes fundamentals and applications. Cambridge: Woodhead Publishing Limited; 2010.

[27] Zhang C, Gamble S, Ainsworth D, Slawin AMZ, Andreev YG, Bruce PG. Alkali metal crystalline polymer electrolytes. Nat Mater 2009;8:580-4.

[28] Wang Y, Chen KS, Mishler J, Cho SC, Adroher XC. A review of polymer electrolyte membrane fuel cells: technology, applications, and needs on fundamental research. Appl Energy 2011;88(4):981-1007.

[29] Stephan AM. Review on gel polymer electrolytes for lithium batteries. Eur Polym J 2006;42(1):21-42.

[30] Fonseca CP, Rosa DS, Gaboardi FA, Neves S. Development of a biodegradable polymer electrolyte for rechargeable batteries. J Power Sources 2006; 155:381-4.

[31] Tarascon JM, Armand M. Issues and challenges facing rechargeable lithium batteries. Nature 2001;414:359-67.

[32] Ozer S, Javorniczky J, Angell CA. Polymer electrolyte photoelectrochemical cells with involatile plasticizers: I. The $\mathrm{n} \mathrm{Si} / \mathrm{I}^{-} / \mathrm{I}_{2}$ cell batteries and energy conversion. J Electrochem Soc 2002;149:A87.

[33] Grätzel M. Dye-sensitized solar cells. J Photochem Photobiol C: Photochem Rev 2003;4:145.

[34] Bhattacharya B, Upadhyaya HM, Chandra S. Photoelectrochemical studies of an ion conducting polymer (PEO)/semiconductor (Si) junction. Solid State Commun 1996;98:633.

[35] Gerischer H, Gobrecht J. On the power characteristics of electrochemical solar cells. Ber Bunsenges Phys Chem 1976;80:327.

[36] Skotheim TA, Inganas O. Polymer solid electrolyte photoelectrochemical cells with n-si-polypyrrole photoelectrodes. J Electrochem Soc 1985;132:2116.

[37] Ellis AB, Kaiser SW, Wrighton MS. Visible light to electrical energy conversion. Stable cadmium sulfide and cadmium selenide photoelectrodes in aqueous electrolytes. J Am Chem Soc 1976;98:1635.

[38] Skotheim TA. Tandem photovoltaic cell using a thinfilm polymer electrolyte. Appl Phys Lett 1981;38:712.

[39] Meyer GJ. The 2010 millennium technology grand prize: dye-sensitized solar cells. ACS Nano 2010;4:4337-43.

[40] Robertson N. Optimizing dyes for dye-sensitized solar cells. Angew Chem Int Ed Engl 2006;45:2338-45.

[41] Yella A, Lee HW, Tsao HN, Yi C, Chandiran AK, Nazeeruddin MK, et al. Porphyrin-sensitized solar cells with cobalt (II/III)-Based redox electrolyte exceed 12\% efficiency. Science 2011;334:629-34.

[42] Grätzel M. Perspectives for dye-sensitized nanocrystalline solar cells. Prog Photovolt Res Appl 2000;8:171.

[43] Hagfeldt A, Grätzel M. Molecular photovoltaics. Acc Chem Res 2000;33:269.

[44] Toyoda T, Sano T, Nakajima J, Doi S, Fukumoto S, Ito A, et al. Outdoor performance of large scale DSC modules. J Photochem Photobiol A: Chem 2004; $164: 203$.

[45] Li B, Wang L, Kang B, Wang P, Qiu Y. Review of recent progress in solid-state dye-sensitized solar cells. Sol Energy Mater Sol Cells 2006;90:549.

[46] O'Regan B, Grätzel M. A low-cost, high-efficiency solar-cell based on dyesensitized colloidal $\mathrm{TiO}_{2}$ films. Nature 1991;353:737-40.

[47] Gratzel M. Photoelectrochemical cells. Nature 2001;414:338-44.

[48] Hardin BE, Snaith HJ, McGehee MD. Renaissance of dye-sensitized solar cells. Nat Photon 2012;6:162.

[49] Narsaiah EL, Reddy MJ, Rao UVS. Study of a new polymer electrolyte $\left(\mathrm{PVP}+\mathrm{KYF}_{4}\right)$ for solid-state electrochemical cells. J Power Sources 1995;55:255.

[50] Yohannes T, Iganas O. Photoelectrochemical studies of the junction between poly[3-(4-octylphenyl)thiophene] and a redox polymer electrolyte. Sol Energy Mater Sol Cells 1998;51:193.

[51] Jung YS, Sathiya PAR, Lim MK, Lee SY, Kim KJ. Influence of amylopectin in dimethylsulfoxide on the improved performance of dye-sensitized solar cells. J Photochem Photobiol A: Chem 2010;209:174-80.

[52] Mathew S, Yella A, Gao P, Humphry BR, Curchod BFE, Astani NA, et al. Dyesensitized solar cells with $13 \%$ efficiency achieved through the molecular engineering of porphyrin sensitizers. Nat Chem 2014;6:242-7.

[53] Bai Y, Cao Y, Zhang J, Wang M, Li R, Wang P, et al. High-performance dyesensitized solar cells based on solvent-free electrolytes produced from eutectic melts. Nat Mater 2008;7:626-30.

[54] Gratzel M. Recent advances in sensitized mesoscopic solar cells. Acc Chem Res 2009;42:1788-98.
[55] Longo C, De Paoli MA. Dye-sensitized solar cells: a successful combination of materials. J Braz Chem Soc 2003;14:889.

[56] Kim YJ, Kim JH, Kang MS, Lee MJ, Won J, Lee JC, et al. Supramolecular electrolytes for use in highly efficient dye-sensitized solar cells. Adv Mater 2004; $16: 1753$.

[57] Kim JH, Kang MS, Kim YJ, Won J, Park NG, Kang YS. Dye-sensitized nanocrystalline solar cells based on composite polymer electrolytes containing fumed silica nanoparticles. Chem Commun 2004:1662-3.

[58] Kang MS, Kim JH, Kim YJ, Won J, Park NG, Kang YS. Dye-sensitized solar cells based on composite solid polymer electrolytes. Chem Commun $2005 ; 889$.

[59] Kang MS, Kim JH, Won J, Kang YS. Oligomer approaches for solid-state dyesensitized solar cells employing polymer electrolytes. J Phys Chem 2007:1115222.

[60] Kang MS, Kim JH, Won J, Kang YS. Dye-sensitized solar cells based on crosslinked poly(ethylene glycol) electrolytes. J Photochem Photobiol A: Chem 2006;183:15.

[61] Kang MS, Ahn KS, Lee JW, Kang YS. Dye-sensitized solar cells employing nonvolatile electrolytes based on oligomer solvent. J Photochem Photobiol A: Chem 2008;195:198.

[62] Ren Y, Zhang Z, Fang S, Yang M, Cai S. Application of PEO based gel network polymer electrolytes in dye-sensitized photoelectrochemical cells. Sol Energy Mater Sol Cells 2002;71:253.

[63] Akhtar MS, Chun JM, Yang OB. Advanced composite gel electrolytes prepared with titania nanotube fillers in polyethylene glycol for the solid-state dyesensitized solar cell. Electrochem Commun 2007;9:2833.

[64] Akhtar MS, Cheralathan KK, Chun JM, Yang OB. Composite electrolyte of heteropolyacid (HPA) and polyethylene oxide (PEO) for solid-state dyesensitized solar cell. Electrochim Acta 2008;53:6623.

[65] Nogueira AF, Vante NA, De Paoli MA. Solid-state photoelectrochemical device using poly (o-methoxy aniline) as sensitizer and an ionic conductive elastomer as electrolyte. Synth Met 1999;105:23.

[66] Nogueira AF, Durrant JR, De Paoli MA. Dye-sensitized nanocrystalline solar cells employing a polymer electrolyte. Adv Mater 2001;13:826.

[67] Nogueira AF, De Paoli MA, Montanari I, Monkhouse R, Nelson J, Durrant JR. Electron transfer dynamics in dye sensitized nanocrystalline solar cells using a polymer electrolyte. J Phys Chem B 2001;105:7517.

[68] Nogueira AF, Spinace MAS, Gazotti WA, Girotto EM, De Paoli MA. Poly (ethylene oxide-co-epichlorohydrin)/Nal: a promising polymer electrolyte for photoelectrochemical cells. Solid State Ion 2001;140:327.

[69] Kim JH, Kang MS, Kim YJ, Won J, Kang YS. Poly(butyl acrylate)/NaI/I $\mathrm{I}_{2}$ electrolytes for dye-sensitized nanocrystalline $\mathrm{TiO}_{2}$ solar cells. Solid State Ion 2005; 176:579.

[70] Kalaignan GP, Kang MS, Kang YS. Effects of compositions on properties of PEO-KI-I ${ }_{2}$ salts polymer electrolytes for DSSC. Solid State Ion 2006;177:1091.

[71] Katsaros G, Stergiopoulos T, Arabatzis IM, Papadokostaki KG, Falaras P. A solvent-free composite polymer/inorganic oxide electrolyte for high efficiency solid-state dye-sensitized solar cells. J Photochem Photobiol A: Chem 2002;149:191.

[72] Chatzivasiloglou E, Stergiopoulos T, Spyrellis N, Falaras P. Solid-state sensitized solar cells, using $\left[\mathrm{Ru}\left(\mathrm{dcbpyH}_{2}\right)_{2} \mathrm{Cl}_{2}\right] \cdot 2 \mathrm{H}_{2} \mathrm{O}$ as the dye and $\mathrm{PEO} /$ titania/ $/ \mathrm{I}^{-} / \mathrm{I}^{3-}$ as the redox electrolyte. J Mater Process Technol 2005; $161: 234$.

[73] Stergiopoulos T, Arabatzis IM, Katsaros G, Falaras P. Binary polyethylene oxide/titania solid-state redox electrolyte for highly efficient nanocrystalline $\mathrm{TiO}_{2}$ photoelectrochemical cells. Nano Lett 2002;2:1259.

[74] Nogueira AF, Longo C, De Paoli MA. Polymers in dye sensitized solar cells: overview and perspectives. Coord Chem Rev 2004;248:1455.

[75] Chen Z, Tang Y, Yang H, Xia Y, Li F, Yi T, Huang C. Nanocrystalline TiO2 film with textural channels: exhibiting enhanced performance in quasi-solid/ solid-state dye-sensitized solar cells. J Power Sources 2007;171:990.

[76] Haque SA, Palomares E, Upadhyaya HM, Otley L, Potter RJ, Holmes AB, et al. Flexible dye sensitised nanocrystalline semiconductor solar cells. Chem Commun 2003:3008.

[77] Anandan S, Pitchumani S, Muthuraaman B, Maruthamuthu P. Heteropolyacid-impregnated PVDF as a solid polymer electrolyte for dye-sensitized solar cells. Sol Energy Mater Sol Cells 2006;90:1715.

[78] Anandan S, Sivakumar R, Tharani P. Solid-state dye-sensitized solar cells constructed with an electrochrome impregnated elastomeric electrolyte. Synth Metals 2008;158:1067.

[79] Ganesan S, Muthuraaman B, Mathew V, Madhavan J, Maruthamuthu P, Suthanthiraraj SA. Performance of a new polymer electrolyte incorporated with diphenylamine in nanocrystalline dye-sensitized solar cell. Sol Energy Mater Sol Cells 2008;92:1718.

[80] Ganesan S, Muthuraaman B, Madhavan J, Mathew V, Maruthamuthu P, Suthanthiraraj SA. The use of 2,6-bis (N-pyrazolyl) pyridine as an efficient dopant in conjugation with poly(ethylene oxide) for nanocrystalline dyesensitized solar cells. Electrochim Acta 2008:53:7903.

[81] Freitas JN, Goncalves AS, De Paoli MA, Durrant JR, Nogueira AF. The role of gel electrolyte composition in the kinetics and performance of dye-sensitized solar cells. Electrochim Acta 2008;53:7166.

[82] Freitas JN, Nogueira AF, De Paoli MA. New insights into dye-sensitized solar cells with polymer electrolytes. J Mater Chem 2009;19:5279.

[83] Flores IC, Freitas JN, Longo C, De Paoli MA, Winnischofer H, Nogueira AF. Dye-sensitized solar cells based on $\mathrm{TiO}_{2}$ nanotubes and a solid-state electrolyte. J Photochem Photobiol A: Chem 2007;189:153. 
[84] Freitas JN, Longo C, Nogueira AF, De Paoli MA. Solar module using dyesensitized solar cells with a polymer electrolyte. Sol Energy Mater Sol Cells 2008;92:1110.

[85] Benedetti JE, De Paoli MA, Nogueira AF. Enhancement of photocurrent generation and open circuit voltage in dye-sensitized solar cells using $\mathrm{Li}+$ trapping species in the gel electrolyte. Chem Commun 2008;1121.

[86] Kang J, Li W, Wang X, Lin Y, Xiao X, Fang S. Polymer electrolytes from PEO and novel quaternary ammonium iodides for dye-sensitized solar cells. Electrochim Acta 2003;48:2487.

[87] Han H, Liu W, Zhang J, Zhao XZ. A Hybrid Poly(ethylene oxide)/ Poly(vinylidene fluoride)/ $/ \mathrm{TiO}_{2}$ nanoparticle solid-state redox electrolyte for dye-sensitized nanocrystalline solar cells. Adv Funct Mater 2005;15:1940.

[88] Zhang J, Han H, Wu S, Xu S, Yang Y, Zhou C, et al. Conductive carbon nanoparticles hybrid PEO/P(VDF-HFP)/SiO 2 nanocomposite polymer electrolyte type dye sensitized solar cells. Solid State Ion 2007;178:1595.

[89] Zhang J, Han H, Wu S, Xu S, Zhou C, Yang Y, et al. Ultrasonic irradiation to modify the $\mathrm{PEO} / \mathrm{P}(\mathrm{VDF}-\mathrm{HFP}) / \mathrm{TiO}_{2}$ nanoparticle composite polymer electrolyte for dye sensitized solar cells. Nanotechnology 2007;18:295606.

[90] Ileperuma OA, Dissanayake MAKL, Somasunderam S, Bandara LRAK. Photoelectrochemical solar cells with polyacrylonitrile-based and polyethylene oxide-based polymer electrolytes. Sol Energy Mater Sol Cells 2004;84:117.

[91] Kumar M, Sekhon SS. Role of plasticizer's dielectric constant on conductivity modification of PEO-NH4 $\mathrm{NH}_{4}$ polymer electrolytes. Eur Polym J 2002:38:1297.

[92] Croce F, Appetecchi GB, Persi L, Scrosati B. Nanocomposite polymer electrolytes for lithium batteries. Nature 1998;394:456.

[93] Preechatiwong W, Schultz JM. Electrical conductivity of poly(ethylene oxide) -alkali metal salt systems and effects of mixed salts and mixed molecular weights. Polymer 1996;37:5109.

[94] Wang GX, Yang L, Wang JZ, Liu HK, Dou SX. Enhancement of ionic conductivity of PEO based polymer electrolyte by the addition of nanosize ceramic powders. J Nanosci Nanotechnol 2005;5:1135.

[95] Yang Y, Zhou C, Xu S, Hu H, Chen B, Zhang J, et al. Improved stability of quasi-solid-state dye-sensitized solar cell based on poly (ethylene oxide)poly (vinylidene fluoride) polymer-blend electrolytes. J Power Sources 2008;185:1492.

[96] Gorlov M, Kloo L. Ionic liquid electrolytes for dye-sensitized solar cells. Dalton Trans 2008;2655.

[97] Iwakia YO, Hernandez Escalonab M, Brionesc JR, Pawlicka A. Sodium Alginate-Based Ionic Conducting Membranes. Molecular Crystals and Liquid Crystals.

[98] Chandra S. Superionic solids: principles and applications. Acta Cryst 1982; A38:878.

[99] Agrawal RC, Pandey GP. Solid polymer electrolytes: materials designing and all-solid-state battery applications: an overview. J Phys D: Appl Phys 2008; $41: 223001$.

[100] Agrawal RC, Gupta RK. Superionic solid: composite electrolyte phase-an overview. J Mater Sci 1999;34(6):1131-62.

[101] Singh R, Jadhav NA, Majumder S, Bhattacharya B, Singh PK. Novel biopolymer gel electrolyte for dye-sensitized solar cell application. Carbohydr Polym 2013;91:682-5.

[102] Weijia W, Xueyi G, Ying Y. Lithium iodide effect on the electrochemical behavior of agarose based polymer electrolyte for dye-sensitized solar cell. Electrochim Acta 2011;56:7347-51.

[103] Siti SA, Ahmad AM. Effect of $\mathrm{NH}_{4} \mathrm{I}$ and $\mathrm{I}_{2}$ concentration on Agar gel polymer electrolyte properties for a Dye-Sensitized Solar Cell. Ionics 2013;19:1185-94.

[104] Jeremy CHK, Zainal AA, Ahmad AM. Bacto agar-based gel polymer electrolyte. Ionics 2012;18(4):359-64.

[105] Hsu HL, Tien CF, Yang YT, Leu J. Dye-sensitized solar cells based on agarose gel electrolytes using allylimidazolium iodides and environmentally benign solvents. Electrochim Acta 2013;91:208-13.

[106] Hsu HL, Tien CF, Leu J. Effect of pore size/distribution in $\mathrm{TiO}_{2}$ films on Agarose gel electrolyte-based Dye-Sensitized Solar Cells. J Solid State Electrochem 2014;18:1665-71.

[107] Hsu HL, Hsu WT, Leu J. Effects of environmentally benign solvents in the Agarose gel electrolytes on Dye-Sensitized Solar Cells. Electrochim Acta 2011;56:5904-9.

[108] Guo X, Yi P, Yang Y, Cui J, Xiao S, Wang W. Effects of surfactants on agarosebased magnetic polymer electrolyte for dye-sensitized solar cells. Electrochim Acta 2013;90:524-9.

[109] Guo XY, Yi PF, Wang WJ, Xiao S, Yang Y. Effects of polyethylene glycol on agarose-based magnetic polymer electrolyte for dye-sensitized solar cell. Adv Mater Res 2013;860:652-4.

[110] Yang Y, Cui J, Yi P, Zheng X, Guo X, Wang W. Effects of nanoparticle additives on the properties of agarose polymer electrolytes. J Power Sources 2014:248:988-93.

[111] Yang Y, Guo XY, Zhao XZ. Influence of polymer concentration on Polysaccharide electrolyte for quasi-Solid-State Dye-Sensitized Solar Cell. Mater Sci Forum 2011;685:76-81.

[112] Yang Y, Hu H, Zhou CH, Xu S, Sebo B, Zhao XZ. Novel agarose polymer electrolyte for quasi-solid state dye-sensitized solar cell. J Power Sources 2011;196:2410-5.

[113] Suzuki K, Yamaguchi M, Kumagai M, Tanabe N, Yanagida S. Dye-sensitized solar cells with ionic gel electrolytes prepared from imidazolium salts and agarose. Comptes Rendus Chim 2006;9(5-6):611-6.

[114] Raphael E, Avellaneda CO, Manzolli B, Pawlicka A. Agar-based films for application as polymer electrolytes. Electrochim Acta 2010;55:1455-9.
[115] Leones R, Sentanin F, Rodrigues LC, Marrucho IM, Esperança JMSS, Pawlicka $\mathrm{A}$, et al. Investigation of polymer electrolytes based on agar and ionic liquids. eXPRESS Polym Lett 2012;6(12):1007-16.

[116] Nemoto J, Sakata M, Hoshi T, Ueno H, Kaneko M. All plastic Dye-Sensitized Solar Cell using a Polysaccharide film containing excess redox electrolyte solution. J Electroanal Chem 2007:599:23-30.

[117] Masao K, Takayuki H, Yuuki K, Hirohito U. Solid type dye-sensitized solar cel using polysaccharide containing redox electrolyte solution. J Electroanal Chem 2004:572:21-7.

[118] Shuhaimi NEA, Alias NA, Majid SR, Arof AK. Electrical double layer capacitor with proton conducting K-Carrageenan-Chitosan electrolytes. Funct Mater Lett 2008;01(03):195-201.

[119] Arof AK, Shuhaimi NEA, Alias NA, Kufian MZ, Majid SR. Application of chitosan/iota-carrageenan polymer electrolytes in electrical double layer capacitor (EDLC). J Solid State Electrochem 2010;14(12):2145-52.

[120] Shuhaimi NEA, Teo LP, Majid SR, Arof AK. Transport studies of $\mathrm{NH}_{4} \mathrm{NO}_{3}$ doped methyl cellulose electrolyte. Synth Metals 2010;160(9-10):1040-4.

[121] Shuhaimi NEA, Alias NA, Kufian MZ, Majid SR, Arof AK. Characteristics of methyl cellulose- $\mathrm{NH}_{4} \mathrm{NO}_{3}-\mathrm{PEG}$ electrolyte and application in fuel cells. J Solid State Electrochem 2010;14(12):2153-9.

[122] Abidin SZZ, Ali AMM, Hassan OH, Yahya MZA. Electrochemical studies on cellulose acetate-LiBOB polymer gel electrolytes. Int J Electrochem Sci 2013:8:7320-6.

[123] Johari NA, Kudin TIT, Ali AMM, Yahya MZA. Electrochemical studies of composite Cellulose Acetate-based polymer gel electrolytes for proton batteries. Proc Natl Acad Sci Sect A: Phys Sci 2012;82(1):49-52.

[124] Saaid SIY, Kudin TIT, Ali AMM, Ahmad AH, Yahya MZA. Solid state proton battery using plasticised cellulose-salt complex electrolyte. Mater Res Innov 2009;13(3):252-4.

[125] Johari NA, Kudin TIT, Ali AMM, Winie T, Yahya MZA. Studies on cellulose acetate-based gel polymer electrolytes for proton batteries. Mater Res Innov 2009;13(3):232-4.

[126] Chelmecki M, Meyer WH, Wegner G. Effect of crosslinking on polymer electrolytes based on cellulose. J Appl Polym Sci 2007;105(1):25-9.

[127] Jafirin S, AhmadI, Ahamad A. Potential use of cellulose from keaf in polymer electrolyte based on MG49 Rubber composites. Bioresources 2013;8 (4):5947-64.

[128] Ramesh S, Shanti R, Morris Ezra. Employment of [Amim] Cl in the effort to upgrade the properties of cellulose acetate based polymer electrolytes. Cellulose 2013;20(3):1377-89.

[129] Harun NI, Ali RM, Ali AMM, Yahya MZA. Dielectric behaviour of cellulose acetate-based polymer electrolytes. Ionics 2012;18(6):599-606.

[130] Ramesh S, Shanti R, Morris Ezra. Discussion on the influence of DES content in CA-based polymer electrolytes. J Mater Sci 2012;47(4):1787-93.

[131] Salvi DTBD, Barud HS, Pawlicka A, Mattos RI, Raphael E, Messaddeq Y, Ribeiro SJL. Bacterial cellulose/triethanolamine based ion-conducting membranes. Cellulose 2014:21:1975-85.

[132] Mishra RK, Anis A, Mondal S, Dutt M, Banthia AK. Preparation and characterization of amidated pectin based polymer electrolyte membranes. Chin J Polym Sci 2009;27(5):639-46.

[133] Mishra RK, Datt M, Banthia AK, Majeed ABA. Development of novel pectin based membranes as proton conducting material. Int J Plast Technol 2012;16 (1):80-8.

[134] Andrade JR, Raphael E, Pawlicka A. Plasticized pectin-based gel electrolytes. Electrochim Acta 2009;54(26):6479-83.

[135] Leones R, Botelho MBS, Sentanin F, Cesarino I, Pawlicka A, Camargo ASS, Silva MM. Pectin-based polymer electrolytes with Ir(III) complexes. Mol Cryst Lic Cryst 2014;1:604.

[136] Singh R, Baghel J, Shukla S, Bhattacharya B, Rhee HW, Singh PK. Detailed electrical measurements on sago starch biopolymer solid electrolyte. Phase Trans: A Multinatl J 2014;87(12):1237-45.

[137] Singh R, Singh PK, Tomar SK, Bhattacharya B. Synthesis, characterization and dye sensitized solar cell fabrication using solid biopolymer electrolyte membranes. High Perform Polym 2016;28:47-54.

[138] Pang SC, Tay CL, Chin SF. Starch-based gel electrolyte thin films derived from native sago (Metroxylon sagu) starch. Ionics 2014;20(10):1455-62.

[139] Yusof YM, Shukur MF, Illias HA, Kadir MFZ. Conductivity and electrical properties of corn starch-chitosan blend biopolymer electrolyte incorporated with ammonium iodide. Phys Scr 2014;89:035701.

[140] Shukur MF, Kadir MFZ. Electrical \& transport properties of $\mathrm{NH}_{4} \mathrm{Br}$-Doped Corn starch Based Solid Biopolymer Electrolyte. Ionics 2015;21:111-24.

[141] Liew CW, Ramesh S. Studies on ionic liquid-based corn starch biopolymer electrolytes coupling with high Ionic transport number. Cellulose 2013;20:3227-37.

[142] Shukur MF, Ithnin R, Kadir MFZ. Electrical characterization of corn starchLiOAc electrolytes and application in electrochemical double layer capacitor Electrochim Acta 2014:136:204-16.

[143] Liew CW, Ramesh S, Ramesh K, Arof AK. Preparation and characterization of lithium ion conducting ionic liquid-based biodegradable corn starch polymer electrolytes. J Solid State Electrochem 2012;16(5):1869-75.

[144] Teoh KH, Lim CS, Ramesh S. Lithium ion conduction in corn starch based solid polymer electrolytes. Measurement 2014;48:87-95.

[145] Ramesh S, Shanti R, Morris E. Studies on the plasticization efficiency of deep eutectic solvent in suppressing the crystallinity of corn starch based polymer electrolytes. Carbohydr Polym 2012;87(1):701-6. 
[146] Shukur MF, Ibrahim FM, Majid NA, Ithnin R, Kadir MFZ. Electrical analysis of amorphous corn starch-based polymer electrolyte membranes doped with LiI. Phys Scr 2013;88:025601.

[147] Saxena H, Bhattacharya B, Jadhav NA, Singh VK, Shukla S, Dubey M. Multiwall carbon-nanotube doped ion conducting polymer electrolyte for electrochemical application. J Exp Nanosci 2014;9:444-51.

[148] Ramesh S, Shanti R, Morris Ezra. Studies on the thermal behavior of CS: LiTFSI:[Amim] Cl polymer electrolytes exerted by different [Amim] $\mathrm{Cl}$ content. Solid State Sci 2012;14(1):182-6.

[149] Ramesh S, Liew CW, Arof AK. Ion conducting corn starch biopolymer electrolytes doped with ionic liquid 1-butyl-3-methylimidazolium hexafluorophosphate. J Non-Cryst Solids 2011;357(21):3654-60.

[150] Teoh KH, Ramesh S, Arof AK. Investigation on the effect of nanosilica toward corn starch-lithium perchlorate-based polymer electrolytes. J Solid State Electrochem 2012;16(10):3165-70.

[151] Ahmed J, Tiwari BK, Imam SH, Rao MA. Starch-Based Polperic Materials and Nanocomposites Chemistry, Processing, and Applications.United States: Taylor \& Francis Group, CRC Press; 2012.

[152] Ning W, Xingxiang Z, Haihui L, Benqiao H. 1-Allyl-3-methylimidazolium chloride plasticized-corn starch as solid biopolymer electrolytes. Carbohydr Polym 2009;76(3):482-4.

[153] Ning W, Xingxiang Z, Haihui L, Jianping WN. N-dimethylacetamide/lithium chloride plasticized starch as solid biopolymer electrolytes. Carbohydr Polym 2009;77(3):607-11.

[154] Ma X, Chang PR, Yua J, Lu P. Characterizations of glycerol plasticized-starch (GPS)/carbon black (CB) membranes prepared by melt extrusion and microwave radiation. Carbohydr Polym 2008;74(4):895-900.

[155] Sankri A, Arhaliass A, Dez I, Gaumont AC, Grohens Y, Lourdin D, Pillin I, Rolland SA, Leroy E. Thermoplastic starch plasticized by an ionic liquid. Carbohydr Polym 2010;82(2):256-63.

[156] Yusof YM, Majid NA, Kasmani RM, Illias HA, Kadir MFZ. The effect of plasticization on conductivity and other properties of starch/chitosan blend biopolymer electrolyte incorporated with ammonium iodide. Mol Cryst Liq Cryst 2014;603:73-88.

[157] Ummartyotin Manuspriya S. An overview of feasibilities and challenge of conductive cellulose for rechargeable lithium based battery. Renew Sustain Energy Rev 2015;50:204-13.

[158] Khanmirzaei MH, Ramesh S. Studies on biodegradable polymer electrolyte rice starch (RS) complexed with lithium iodide. Ionics 2014;20:691-5.

[159] Khanmirzaei MH, Ramesh S. Ionic transport and FTIR properties of lithium iodide doped biodegradable rice starch based polymer electrolytes. Int J Electrochem Sci 2013;8:9977-91.

[160] Khanmirzaei MH, Ramesh S. Nanocomposite polymer electrolyte based on rice starch/ionic liquid/ $/ \mathrm{TiO}_{2}$ nanoparticles for solar cell application. Measurement 2014;58:68-72.

[161] Tiwari T, Srivastava N, Srivastava PC. Ion dynamics study of potato starch + sodium salts electrolyte system. Int J Electrochem 2013;2013:8.

[162] Tiwari T, Srivastava N, Srivastava PC. Electrical transport study of potato starch-based electrolyte system. Ionics 2011;17:353-60.

[163] Kumar M, Tiwari T, Srivastava N. Electrical transport behaviour of bio-polymer electrolyte system: potato starch + ammonium iodide. Carbohydr Polym 2012;88:54-60.

[164] Tiwari T, Kumar M, Srivastava N, Srivastava PC. Electrical transport study of potato starch-based electrolyte system-II. Mater Sci Engo B 2014:182:6-13.

[165] Zhao S, Wang CY, Chen MM, Wang J, Shi ZQ. Potato starch-based activated carbon spheres as electrode material for electrochemical capacitor. J Phys Chem Solids 2009;70:1256-60.

[166] Singh R, Bhattacharya B, Rhee HW, Singh PK. New biodegradable polymer electrolyte for dye sensitized solar cell. Int J Electrochem Sci 2014;9:2620-30.

[167] Tiwari T, Pandey K, Srivastava N, Srivastava PC. Effect of glutaraldehyde on electrical properties of arrowroot starch $+\mathrm{NaI}$ electrolyte system. J Appl Polym Sci 2011;121(1):1-7.

[168] Khiar ASA, Arof AK. Electrical properties of starch/chitosan- $\mathrm{NH}_{4} \mathrm{NO}_{3}$ polyme electrolyte. Int J Math, Comput, Phys, Electr Comput Eng 2011;5(11):1662-7.

[169] Mallick H, Sarkar A. An experimental investigation of electrical conductivities in biopolymers. Bull Mater Sci 2000;23(4):319-24.

[170] Singh D, Singh PK, Jadhav NA, Bhattacharya B. Electrostatic model of semiconductor nanoparticles trapped in polymer electrolytes. Bull Mater Sci 2013;36:977-80.

[171] Park SJ, Yoo K, Kim JY, Kim JY, Lee DK, Kim B, Kim H, Kim JH, Cho J, Ko MJ. Water-based thixotropic polymer gel electrolyte for dye-sensitized solar cells ACS Nano 2013;7(5):4050-6.

[172] Noor ISM, Majid SR, Arof AK, Djurado D, Claro Neto S, Pawlicka A. Characteristics of gellan gum-LiCF3SO3 polymer electrolytes. Solid State Ion 2012;225:649-53.

[173] Halim NFA, Majid SR, Arof AK, Kajzar F, Pawlicka A. Gellan gum-lii gel polymer electrolytes. Mol Cryst Liquid Cryst 2012;554:232-8.

[174] Higgins TM, Moulton SE, Gilmore KJ, Wallace GG, in het Panhuis M. Gellan gum doped polypyrrole neural prosthetic electrode coatings. Soft Matter 2011;7(10):4690-5.

[175] Singh PK, Bhattacharya B, Nagarale RK, Kim KW, Rhee HW. Synthesis, characterization and application of biopolymer-ionic liquid composite membranes. Synth Metals 2010;160:139-42.

[176] Hassan F, Woo HJ, Aziz NA, Kufian MZ, Majid SR. Synthesis of $\mathrm{Al}_{2} \mathrm{TiO}_{5}$ and its effect on the properties of chitosan- $\mathrm{NH}_{4} \mathrm{SCN}$ polymer electrolytes. Ionics $2013 ; 19: 483-9$.
[177] Mohamed NS, Subban RHY, Arof AK. Polymer batteries fabricated from lithium complexed acetylated chitosan. J Power Sources 1995;56:153-6.

[178] Buraidah MH, Teo LP, Majid SR, Arof AK. Characteristics of $\mathrm{TiO}_{2} /$ solid electrolyte junction solar cells with $\mathrm{I}^{-} / \mathrm{I}^{3-}$ redox couple. Opt Mater 2010;32:7238.

[179] Buraidah MH, Teo LP, Yusuf SNF, Noor MM, Kufian MZ, Careem MA, Majid SR, Taha RM, Arof AK. TiO 2 /chitosan- $\mathrm{NH}_{4} \mathrm{I}\left(+\mathrm{I}_{2}\right)$-BMII-based dye-sensitized solar cells with anthocyanin dyes extracted from black rice and red cabbage. Int J Photoenergy 2011 Article ID 273683, 11 pages.

[180] Mohamad SA, Yahya R, Ibrahim ZA, Arof AK. Photovoltaic activity in a ZnTe/ PEO-chitosan blend electrolyte junction. Solar Energy Mater Solar Cells 2007;91(13):1194-8

[181] Singh VK, Annu A, Singh U, Singh P, Pandey SP, Bhattacharya B, Singh PK. Dye sensitized solar cell based on poly (vinyl alcohol) doped with ammonium iodide solid polymer electrolyte. J Optoelectron Adv Mater 2013;15:927-31.

[182] Ahmad KAS, Puteh R, Arof AK. Characterizations of chitosan-ammonium triflate $\left(\mathrm{NH}_{4} \mathrm{CF}_{3} \mathrm{SO}_{3}\right)$ complexes by FTIR and impedance spectroscopy. Phys Stat Sol A 2006;203(3):534-43.

[183] Hamdan KZ, Khiar ASA. Conductivity and Dielectric Studies of Methylcellulose/Chitosan- $\mathrm{NH}_{4} \mathrm{CF}_{3} \mathrm{SO}_{3}$ Polymer Electrolyte. Key Eng Mater 2014;594/595:812.

[184] Yahya MZA, Arof AK. Conductivity and X-ray photoelectron studies on lithium acetate doped chitosan films. Carbohydr Polym 2004;55(1):95-100.

[185] Yahya MZA, Arof AK. Effect of oleic acid plasticizer on chitosan-lithium acetate solid polymer electrolytes. Eur Polym J 2003;39(5):897-902.

[186] Yahya MZA, Arof AK. Characteristics of chitosan-lithium acetate-palmitic acid complexes. J New Mater Electrochem Systems 2002;5:123-8.

[187] Shukur MF, Ithnin R, Kadir MFZ. Electrical properties of proton conducting solid biopolymer electrolytes based on starch-chitosan blend. Ionics 2014;20 (7):977-99.

[188] Majid SR, Arof AK. Proton-conducting polymer electrolyte films based on chitosan acetate complexed with $\mathrm{NH}_{4} \mathrm{NO}_{3}$ salt. Phys B: Condens Matter 2005;355(1-4):78-82.

[189] Jamaludin A, Mohamad AA. Application of liquid gel polymer electrolyte based on chitosan- $\mathrm{NH}_{4} \mathrm{NO}_{3}$ for proton batteries. J Appl Polym Sci 2010;118 (2):1240-3.

[190] Ng LS, Mohamad AA. Protonic battery based on a plasticized chitosan- $\mathrm{NH}_{4} \mathrm{NO}_{3}$ solid polymer electrolyte. J Power Sources 2006;163 (1):382-5.

[191] Kadir MFZ, Aspanut Z, Yahya R, Arof AK. Chitosan-PEO proton conducting polymer electrolyte membrane doped with $\mathrm{NH}_{4} \mathrm{NO}_{3}$. Mater Res Innov $2011 ; 15: 164-7$.

[192] Winie T, Arof AK. Transport properties of hexanoyl chitosan-based gel electrolyte. Ionics 2006;12:149-52.

[193] Bakar NY, Isa MIN. Potential of Ionic conductivity and transport properties solid biopolymer electrolytes based carboxy methylcellulose/ chitosan polymer blend doped with dodecyltrimethyl ammonium bromide. Res J Recent Sci 2014;3(10):69-74.

[194] Kadir MFZ, Majid SR, Arof AK. Plasticized chitosan-PVA blend polymer electrolyte based proton battery. Electrochim Acta 2010;55(4):1475-82.

[195] Kadir MFZ, Arof AK. Application of PVA-chitosan blend polymer electrolyte membrane in electrical double layer capacitor. Mater Res Innov 2011;15(2): S217-20.

[196] Buraidah MH, Arof AK. Characterization of chitosan/PVA blended electrolyte doped with $\mathrm{NH}_{4} \mathrm{I}$. J Non-Cryst Solids 2011;357(16-17):3261-6.

[197] Buraidah MH, Teo LP, Majid SR, Yahya R, Taha RM, Arof AK. Characterizations of Chitosan-Based Polymer Electrolyte Photovoltaic Cells. Int J Photoenergy 2010 2010: 7 Article ID 805836.

[198] Tan Winie, Ramesh S, Arof AK. Studies on the structure and transport properties of hexanoyl chitosan-based polymer electrolytes. Physica B 2009:404:4308-11.

[199] Majid SR, Arof AK. Conductivity studies and performance of chitosan based polymer electrolytes in $\mathrm{H}_{2}$ /air fuel cell. Polym Adv Technol 2009;20(6):524-8.

[200] Idris NH, Senin HB, Arof AK. .Dielectric spectra of LiTFSI-doped chitosan/PEO blends. Ionics 2007;13(4):213-7.

[201] Tan Winie, Arof AK. Hexanoyl chitosan-based gel electrolyte for use in lithium-ion cell. Polym Adv Technol 2006;17(7-8):552-5.

[202] Yahya MZA, Ali AMM, Mohammat MF, MAKM Hanafiah, Mustaffa M, Ibrahim SC, Darus ZM, Harun MK. Ionic conduction model in salted chitosan membranes plasticized with fatty acid. J Appl Sci 2006;6:1287-91.

[203] Nawaz A, Sharif R, Rhee HW, Singh PK. Efficient dye sensitized solar cell and supercapacitor using 1-ethyl 3-methyl imidazolium dicyanamide incorporated PVDF-HFP polymer matrix. J Ind Eng Chem 2016;33:381-4.

[204] Yusof YM, Illias HA, Kadir MFZ. Incorporation of $\mathrm{NH}_{4} \mathrm{Br}$ in PVA-chitosan blend-based polymer electrolyte and its effect on the conductivity and other electrical properties. Ionics 2014;20:1235-45.

[205] Rathod SG, Bhajantri RF, Ravindrachary V, Pujari PK, Sheela T. Ionic conductivity and dielectric studies of $\mathrm{LiClO}_{4}$ doped poly(vinylalcohol)(PVA)/ chitosan(CS) composites. Compos J Adv Dielectr 2014;4(4):1450033.

[206] Singh VK, Bhattacharya B, Shukla S, Singh PK. New solid polymer electrolyte material for dye sensitized solar cells. Mater Tehnol 2015;49:123-7.

[207] Ummartyotin S, Manuspiya A. Critical review on cellulose: from fundamental to an approach on sensor technology. Renew Sustain Energy Rev 2015;41:402-12.

[208] Shukur MF, Ithnin R, Kadir MFZ. Protonic transport analysis of starch- chitosan blend based electrolytes and application in electrochemical device. Mol Cryst. Liq Cryst 2014;603:52-65. 
[209] Shukur MF, Majid NA, Ithnin R, Kadir MFZ. Effect of plasticization on the conductivity and dielectric properties of starch-chitosan blend biopolymer electrolytes infused with $\mathrm{NH}_{4} \mathrm{Br}$. Phys Scr 2013;T157:014051.

[210] Kamarulzaman N, Osman Z, Muhamad MR, Ibrahim ZA, Arof AK, Mohamed NS. Performance characteristics of $\mathrm{LiMn}_{2} \mathrm{O}_{4} /$ polymer/carbon electrochemical cells. J Power Sources 2001;97-98:722-5.

[211] Osman Z, Ibrahim ZA, Arof AK. Conductivity enhancement due to ion dissociation in plasticized chitosan based polymer electrolytes. Carbohydr Polym 2001;44:167-73.

[212] Subban RHY, Arof AK, Radhakrishna S. Polymer batteries with chitosan electrolyte mixed with sodium Perchlorate. Mater Sci Eng B 1996;38:156-60.

[213] Samsudin AS, Isa MIN. Structural and ionic transport study on CMC doped $\mathrm{NH}_{4} \mathrm{Br}$ : a new types of biopolymer electrolytes. J Appl Sci 2012;12:174-9.

[214] Ramlli MA, Isa MIN. Conductivity study of carboxyl methyl cellulose Solid biopolymer electrolytes (SBE) doped with Ammonium. Fluoride Res J Recent Sci 2014;3(6):59-66.

[215] Ahmad Z, Isa MIN. Ionics conduction via correlated barrier hoping mechanism in CMC-SA solid biopolymer electrolytes. Int J Latest Res Sci Technol 2012;1(2):70-5.

[216] Isa MIN, Samsudin AS. Ionic Conduction behavior of CMC based green polymer electrolytes. Adv Mater Res 2013;802:194.

[217] Rani MSA, Siti Rudhziah, Azizan Ahmad, Mohamed NS. Biopolymer electrolyte based on derivatives of cellulose from kenaf bast fiber. Polymers 2014;6 (9):2371-85.

[218] Chai MN, Isa MIN. The oleic acid composition effect on the carboxymethyl cellulose based biopolymer electrolyte. J Cryst Process Technol 2013;3:1-4.

[219] Shuhaimi NEA, Teo LP, Majid SR, Arof AK. Transport studies of $\mathrm{NH}_{4} \mathrm{NO}_{3}$ doped methyl cellulose electrolyte. Synth Metals 2010;160(9):1040-4.

[220] Nik Aziz NA, Idris NK, Isa MIN. Solid Polymer electrolytes based on methylcellulose: FT-IR and ionic conductivity studies. Int J Polym Anal Charact 2010;15(5):319-27.

[221] Samsudin AS, Kuan ECH, Isa MIN. Investigation of the potential of protonconducting biopolymer electrolytes based methyl cellulose-glycolic acid. Int J Polymr Anal Charact 2011;16(7):477-85.

[222] Harun NI, Sabri NS, Rosli NHA, Taib MFM, Saaid SIY, Kudin TIT, Ali AMM, Yahya MZA. Proton conductivity studies on biopolymer electrolytes. AIP Conf Proc 2010;1250:237.

[223] Xiao SY, Yang YQ, Li MX, Wang FX, Chang Z, Wu YP, Liu X. A composite membrane based on a biocompatible cellulose as a host of gel polymer electrolyte for lithium ion batteries. J Power Sources 2014:270:53-8.

[224] Shuhaimi NEA, Alias NA, Kufian MZ, Majid SR, Arof AK. Characteristics of methyl cellulose- $\mathrm{NH}_{4} \mathrm{NO}_{3}$-PEG electrolyte and application in fuel cells. J Sol State Electrochem 2010;14(12):2153-9.

[225] Polu AR, Kim DK, Rhee HW. Poly(ethylene oxide)-lithium difluoro(oxalato) borate new solid polymer electrolytes: ion-polymer interaction, structural, thermal, and ionic conductivity studies. Ionics 2015;21:2771-80.

[226] Polu AR, Kumar R. $\mathrm{Mg}^{2+}$-ion Conducting PEG-TiO 2 Composite Polymer Electrolytes for Solid-State Batteries. Mater Express 2014;4:79-84.

[227] Dygas JR, Misztal-Faraj B, Florjanczyk Z, Krok F, Marzantowicz M, ZygadloMonikowska E. Effects of inhomogeneity on ionic conductivity and relaxations in PEO and PEO-salt complexes. J Solid State Ion 2003:157:249-56.

[228] Kovac M, Gaberscek M, Gradadolnik J. The effect of plasticizer on the microstructural and electrochemical properties of a $(\mathrm{PEO}) \mathrm{nLiAl}\left(\mathrm{SO}_{3} \mathrm{Cl}\right)_{4}$ system. Electrochim Acta 1998:44:863-8.

[229] Armand MB, Chabagno JM, Duclot MJ. In: Vashista P, Shenoy GK, editors. Fast ion transport in solids. North Holland: Elsevier; 1979. p. 131.

[230] Bertheir C, Gorecki W, Minier M, Armand MB, Chanbagno JM, Rigaud P. Microscopic investigation of ionic conductivity in alkali metal salts-poly (ethylene oxide) adducts. Solid State Ion 1983;11:91-8.

[231] Machado GO, Ferreira HCA, Pawlicka A. Influence of plasticizer contents on the properties of HEC based solid polymeric electrolytes. Electrochim Acta 2005;50:3827-31.

[232] Mattos RI, Tambelli C, Donoso JP, Pawlicka A. NMR study of starch based polymer gel electrolytes: humidity effects. Electrochim Acta 2007:53:1461-8.

[233] Pawlicka A, Danczuk M, Wieczorek W, Zygadlo-Monikowska E. Influence of plasticizer type on the properties of polymer electrolytes based on chitosan. J Phys Chem A 2008;112:8888-96.

[234] Shuhaimi NEA, Alias NA, Majid SR, Arof AK. Electrical double layer capacitor with proton conducting k-carrageenan-chitosan-electrolytes. Funct Mater Lett 2008;1(3):195-201.

[235] Idris NH, Majid SR, Khiar ASA, Hassan MF, Arof AK. Conductivity studies on chitosan/PEO blends with LiTFSI salt. Ionics 2005;11:375-7.

[236] Fuentes S, Retuert J, Gonzalez G. Transparent conducting polymer electrolyte by addition of lithium to the molecular complex chitosane-poly(aminopropyl siloxane). Electrochim Acta 2003;48:2015-21.

[237] Morni NM, Arof AK. Chitosan lithium triflate electrolyte in secondary lithium cells. J Power Sources 1999;77(1):42-8.

[238] Yahya MZA, Arof AK. Effect of oleic acid plasticizer on chitosan lithium acetate solid polymer electrolytes. Eur Polym J 2003;39(5):897-902.

[239] Klemm D, Heublein B, Fink H-P, Bohn A. Cellulose: fascinating biopolymer and sustainable raw material. Angew Chem Int Ed 2005;44:3358-93.

[240] Klemm D, Kramer F, Moritz S, Lindström T, Ankerfors M, Gray D, Dorris A. Nanocelluloses: a new family of nature-based materials. Angew Chem Int Ed 2011;50:5438-66.

[241] Jabbour L, Bongiovanni R, Chaussy D, Gerbaldi C, Beneventi D. Cellulosebased Li-ion batteries: a review. Cellulose 2013;20(4):1523-45.
[242] Samsudin AS, Lai HM, Isa MIN. Biopolymer materials based carboxymethyl cellulose as a proton conducting biopolymer electrolyte for application in rechargeable proton battery. Electrochim Acta 2014;129:1-13.

[243] Rani MSA, Rudhziah S, Ahmad A, Mohamed NS. Biopolymer electrolyte based on derivatives of cellulose from kenaf bast fiber. Polymers 2014:6:2371-85.

[244] Ramesh S, Shanti R, Morris E. Plasticizing effect of 1-allyl-3-methylimidazolium chloride in cellulose acetate based polymer electrolytes. Carbohydr Polym 2012;87:2624-9.

[245] Jabbour L. Elaboration of Li-ion batteries using cellulose fibers and paper making techniques. Docteur De L'Université De Grenoble. 2012; 〈http://www. theses.fr/2012GRENI043.pdf).

[246] Nair JR, Gerbaldi C, Chiappone A, et al. UV-cured polymer electrolyte membranes for Li-cells: improved mechanical properties by a novel cellulose reinforcement. Electrochem Commun 2009;11:1796-8.

[247] Nair JR, Chiappone A, Gerbaldi C, et al. Novel cellulose reinforcement for polymer electrolyte membranes with outstanding mechanical properties. Electrochim Acta 2009;57:104-11.

[248] Wang CG, Yuan WN, Lu NQ. Studies on preparation and properties of novel gel. Polym Electrolyte Adv Mater Res 2010;123-125:226-30.

[249] Azizi SMAS, Alloin F, Dufresne A. High performance nanocomposite polymer electrolytes. Compos Interface 2006;13:545-59.

[250] Azizi SMAS, Alloin F, Sanchez JY, Dufresne A. Cross-linked nanocomposite polymer electrolytes reinforced with cellulose whiskers. Macromolecules 2004;37:4839-44.

[251] SMAS Azizi, Chazeau L, Alloin F, et al. POE-based nanocomposite polymer electrolytes reinforced with cellulose whiskers. Electrochim Acta 2005:50:3897-903.

[252] Schroers M, Kokil A, Weder C. Solid polymer electrolytes based on nanocomposites of ethylene oxide-epichlorohydrin copolymers and cellulose whiskers. J Appl Polym Sci 2004:93:2883-8.

[253] Alloin F, D’Aprea A, Kissi NE, et al. Nanocomposite polymer electrolyte based on whisker or microfibrils polyoxyethylene nanocomposites. Electrochim Acta 2010;55:5186-94.

[254] Chiappone A. Ligno-cellulosic materials for energy storage. Politecnico di Torino: Turin; 2011. 〈http://porto.polito.it/2496830〉.

[255] Chelmecki M, Meyer WH, Wegner G. Effect of crosslinking on polymer electrolytes based on cellulose. J Appl Polym Sci 2007:105:25-9.

[256] Lee JM, Nguyen DQ Lee SB, et al. Cellulose triacetatebased polymer gel electrolytes. J Appl Polym Sci 2010;115:32-6.

[257] Machado GO, Ferreira HCA, Pawlicka A. Influence of plasticizer contents on the properties of HEC-based solid polymeric electrolytes. Electrochim Acta 2005;50:3827-31.

[258] Paracha RN, Ray S, Easteal AJ. Grafting of LiAMPS on ethyl cellulose: a route to the fabrication of superior quality polyelectrolyte gels for rechargeable Lithium ion batteries. J Mater Sci 2012;47:3698-705.

[259] Ramesh S, Shanti R, Morris E. Plasticizing effect of 1-allyl-3-methylimidazolium chloride in cellulose acetate based polymer electrolytes. Carbohydr Polym 2012;87:2624-9.

[260] Ko YG, Khasbaatar AD, Choi US, Kim J-Y. Molecular interaction mechanism in solid polymer electrolyte comprising cellulose phthalate and $\mathrm{LiClO}_{4}$. Solid State Ion 2010;181:1178-82.

[261] Sato T, Banno K, Maruo T, Nozu R. New design for a safe lithium-ion gel polymer battery. J Power Sources 2005;152:264-71.

[262] Ren Z, Liu Y, Sun K, et al. A microporous gel electrolyte based on poly (vinylidene fluoride-co-hexafluoropropylene)/ fully cyanoethylated cellulose derivative blend for lithiumion battery. Electrochim Acta 2009;54:1888-92.

[263] Yue Z, McEwen I, Cowie JM. Novel gel polymer electrolytes based on a cellulose ester with PEO side chains. Solid State Ion 2003;156:155-62.

[264] Regiani AM, de Oliveira Machado G, LeNest J-F, et al. Cellulose derivatives as solid electrolyte matrixes. Macromol Symp 2001:175:45-54.

[265] RFMS Marcondes, D'Agostini PS, Ferreira J, Girotto EM, Pawlicka A, Dragunsk DC. Solid State Ion 2010;181:586-91.

[266] Lopes LVS, Dragunski DC, Pawlicka A, Donoso JP. Nuclear magnetic resonance and conductivity study of starch based polymer electrolytes. Electrochim Acta 2003;48:2021-7.

[267] Navaratnam S, Ramesh K, Ramesh S, Sanusi A, Basirun WJ, Arof AK. Transport mechanism studies of chitosan electrolyte systems. Electrochim Acta 2015; 175:68-73.

[268] Alias SS, Ariff ZM, Mohamad AA. Porous membrane based on chitosan-SiO for coin cell proton battery. Ceram Int 2015;41:5484-91.

[269] Taib NU, Idris NH. Plastic crystal-solid biopolymer electrolytes for rechargeable lithium batteries. J Membr Sci 2014;468:149-54.

[270] Alves RD, Rodrigues LC, Andrade JR, Pawlicka A, Pereira L, Martins R, Fortunato E, Silva MM. Study and characterization of a novel polymer electrolyte based on agar doped with magnesium triflate. Mol Cryst Liq Cryst 2013;570:1-11.

[271] Leones R, Sentanin F, Rodrigues LC, Marrucho IM, Esperança JMSS, Pawlicka A, Silva MM. Investigation of polymer electrolytes based on agar and ionic liquids. Exp Polym Lett 2012;6:1007-16.

[272] Stojadinović J, Dushina A, Trócoli R, Mantia FL. Electrochemical characterization of gel electrolytes for aqueous Lithium-Ion batteries. ChemPlusChem 2014;79(10):1507-11.

[273] Audeh DJSA, Alcazar JB, Barbosa CV, Carreno NLV, Avellaneda CAO. Influence of the NiO nanoparticles on the ionic conductivity of the agar-based electrolyte. Polímeros 2014;24:8-12. 
[274] Leones R, Botelho MBS, Sentanin F, Cesarino I, Pawlicka A, Camargo ASS, Silva MM. Pectin-based polymer electrolytes with Ir(III) complexes. Mol Cryst Liq Cryst 2014;604:117-25.

[275] Barker RE, Thomas CR. Effects of moisture and high electric fields on conductivity in alkali-halide-doped cellulose acetate. J Appl Phys 1964;35:320316.

[276] Lu DR, Xiao CM, Xu SJ. Starch-based completely biodegradable polymer materials. Exp Polym Lett 2009;3(6):366-75.

[277] Elizabeth P. The polysaccharides of green, red and brown seaweeds: their basic structure, biosynthesis and function. Br Phycol J 1979;14:103-17.

[278] Majda S, Pierre L. A spectroscopic investigation of the carrageenans and agar in the1500-100 $\mathrm{cm}^{-1}$ spectral range. Spectrochim Acta 1993;49A(2):209-21.

[279] Babak G, Hadi A. Biodegradable Polymers. 〈http://Dx.Doi.Org/10.5772/ 56230>.

[280] Ave RL. Biodegradable multiphase systems based on plasticized starch: a review. J Macromol Sci Part C Polym Rev 2004;C44(3):231-74.

[281] Bai Y, Cao Y, Zhang J, Wang M, Li R, Wang P, Zakeeruddin SM, Grätzel M. High-performance dye-sensitized solar cells based on solvent-free electrolytes produced from eutectic melts. Nat Mater 2008;7:626.

[282] Kuang D, Klein C, Zhang Z, Ito S, Moser JE, Zakeeruddin SM, Grätzel M. Stable, high-efficiency ionic-liquid-based mesoscopic dye-sensitized solar cells. Small 2007;3:2094.

[283] Bonhote P, Dias AP, Papageorgiou N, Kalyanasundaram K, Grätzel M. Hydrophobic, highly conductive ambient-temperature molten salts. Inorg Chem 1996;35:1168.
[284] Singh PK, Kim KI, Lee JW, Rhee HW. Polymer electrolyte with ionic liquid for DSSC application. Phys Stat Sol A 2006;R88:203.

[285] Surana K, Mehra RM, Bhattacharya B, Rhee HW, Polu AR, Singh PK. A comprehensive study of chalcogenide quantum dot sensitized solar cells with a new solar cell exceeding $1 \mathrm{~V}$ output. Renew Sustain Energy Rev 2015;52:1083-92.

[286] Singh PK, Kim KW, Kim KI, Park NG, Rhee HW. Nanocrystalline porous $\mathrm{TiO}_{2}$ electrode with ionic liquid impregnated solid polymer electrolyte for dye sensitized solar cells. J Nanosci Nanotechnol 2008;8:5271.

[287] Singh PK, Kim KW, Rhee HW. Electrical, optical and photoelectrochemical studies on a PEO-polymer electrolyte doped with low viscosity ionic liquid. Electrochem Commun 2008;10:1769.

[288] Singh PK, Kim KW, Park NG, Rhee HW. Mesoporous nanocrystalline $\mathrm{TiO}_{2}$ electrode with ionic liquid based solid polymer electrolyte for dye sensitized solar cell application. Synth Metals 2008;158:590.

[289] Singh PK, Kim KW, Rhee HW. Ionic liquid (1-methyl 3-propyl imidazolium iodide) with polymer electrolyte for DSSC application. Polym Eng Sci 2009;49:862.

[290] Singh PK, Bhattacharya B, Nagarale RK, Pandey SP, Kim KW, Rhee HW. Ionic liquid doped poly (N-methyl 4-vinylpyridine iodide) solid polymer electrolyte for dye sensitized solar cell. Synth Metals 2010;160:950. 